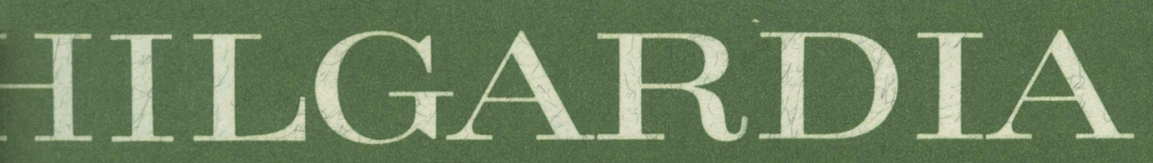

OURNAL OF AGRICULTURAL SCIENCE PUBLISHED BY E CALIFORNIA AGRICULTURAL EXPERIMENT STATION

Volume 52, Number $1 \bullet$ January 1984

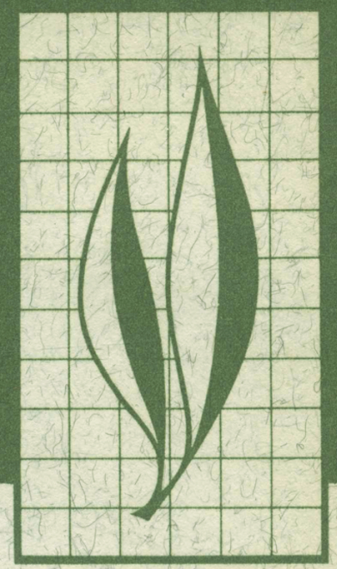

\title{
Environmentally Related Restrictions on the Timber Harvesting Capability of a National Forest: A Case Study
}

Robert J. Hrubes 


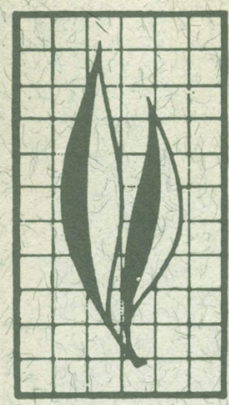

In response to influences predominantly external to the United States Department of Agriculture, Forest Service, and beginning in the 1970s, the latitude and intensity of timber management activities on the National Forests have been increasingly limited through the imposition of environmentally induced constraints. Quantitative information on the relative costs and benefits of imposing environmentally induced constraints is generally lacking, and this has hindered the proper evaluation of the constraints. To generate some of this needed information, the author examined the effects of meeting environmental goals on National Forest timber harvesting capability by developing 20 simulated harvest schedules for a case study in northern California. Using available data and the simulation model FORPLAN, the schedules were designed to identify the effects of land withdrawal, retention of old-growth stands, minimum rotation, geographic dispersion, and limitation on the use of herbicides on allowable timber cutting. Monitored indices included first-decade harvesting, total harvest in the first five decades, long-run sustainedyield average, species concentration, acres clearcut, and distribution of ending-age classes. In addition, these economic indices were monitored by two demand formulations (present net worth and present net benefit after 16 decades), total costs and revenues in the first decade, and cost per million cubic feet. Two different price assumptions were modeled - each representing distinctly contrasting conditions. The results suggest that the allowable harvest capability of the case-study forest was significantly reduced when measures were taken to reach environmental goals.

\section{THE AUTHOR:}

Robert J. Hrubes, former Research Assistant in the Department of Forestry and Resource Management, University of California, Berkeley, has returned to his position as Forest Economist at the United States Department of Agriculture, Forest Service, Pacific Southwest Forest and Range Experiment Station, Berkeley, California. 


\section{Environmentally Related Restrictions on the Timber Harvesting Capability of a National Forest: A Case Study ${ }^{1}$}

\section{INTRODUCTION}

THE MANAGEMENT OF the National Forests can be viewed as the administration of a multi-product production process in which the mix of products has experienced continuous change since its establishment. Definition of the preferred mix of goods and services to be produced on the National Forests has historically resulted from a combination of factors, such as: 1) the professional initiative of the Forest Service managers; 2) the pressures of public interest, exercised through direct and indirect channels (e.g., direct input to the Forest Service, lawsuits, congressional action); and 3) policy directives issued by the President and administration.

The relative importance of the roles these forms of influence have played in setting Forest Service policies and management programs has also been in a state of continuous change. Beginning with the decade of the 1970s (what has been called the "environmental era"), the influence exerted by factors external to the Forest Service increased dramatically. Public concern for the environment brought profound changes in the management of the National Forests. These management changes have been the results of farreaching institutional changes within the agency, including rapid growth in the number of specialists who are not foresters, increased involvement of the public and other agencies in National Forest management and decision making, and development of a participatory planning system that brought with it an elevated concern for noncommodity aspects of forest management (Hrubes, 1981). The environmental awareness that gained widespread support in the 1970s has brought about an increased public demand for the production or protection of environmental and noncommodity amenities of the National Forests.

Because of its traditionally dominant role and its inherent conflicts with the environmental and noncommodity character of forest lands, the Forest Service's timber management program is among the programs most severely limited by environmental considerations. Constraints imposed because of concern for environmental quality include limitations on the use of such silvicultural tools as herbicides and prescribed burning, requirements on the spacing and timing of harvests, and limitations on the land area available for timber harvesting. These constraints serve to limit the latitude and intensity of management activities supporting the efficient production and harvesting of timber from the National Forests. As such, the imposition of constraints results in costs incurred by the timber management program-costs realized in terms of foregone timber production and harvest capability and in higher capital and labor outlays per unit of production or harvest. As the constraints become increasingly severe, the goals of timber management become increasingly difficult to attain, and the monetary cost of their attainment rises. Of course, the rationale for imposing environmentally induced constraints is to prevent or limit those environmental, political, and aesthetic costs that arise from timber management activities.

\footnotetext{
${ }^{1}$ Accepted for publication June 9, 1983.
} 
Implicit in the imposition of these constraints is an evaluation that the costs they generate (incurred by the timber management program) are more than offset by the benefits they generate (by preventing or limiting environmental, political, and aesthetic costs). In fact, this type of evaluation generally has not been carried out. Whether or not these constraints on timber management activities are justified in terms of the costs and benefits they generate has been a point of great debate-debate which has involved professional land managers, resource specialists, environmental and industry groups, and the concerned lay-public. The debate has been all the more intense and inconclusive because of the general lack of quantitative information about what is accomplished by the environmentally induced constraints and what their impacts are on the timber production and harvest capabilities of the National Forests.

The research on which this report is based did not attempt to examine the benefit side of the constraints' ledger. Before a final evaluation of their social merit can be made, this must be done. What this research did set out to do was to generate quantitative estimates of the effect that environmentally induced constraints exert on the timber harvest capability of a single National Forest. To accomplish this, I conducted a case study on the Six Rivers National Forest in northern California. The study used a simulation technique, and was designed to answer this question: What is the cost-in terms of foregone timber harvest capability and associated revenues-of meeting environmental goals and granting priority to nonmarket goods and services?

This paper reports the result of the case study which simulated the land management planning process of this National Forest. It examines the sensitivity of the forest's allowable harvest to the environmental constraints that are now being imposed on most forests in the western United States.

\section{SIMULATING FOREST PLANNING}

\section{Forest plan specifications}

A series of simulated forest plans was developed by using the Forest Service's computer model FORPLAN (Johnson, 1979). Only the output scheduling phase of the planning process was simulated. Each plan differed from the others in one or more of the following respects:

- The specification of environmentally induced constraints

- The land base available for timber production

- The objective function driving the scheduling process

In this way the effects of individual constraints could be isolated, as could the interactive effects of several when simultaneously imposed. The intent was to estimate what the actual effects might be when the next forest plan for the case forest is developed and implemented, so the case study used the same data available to and used by the forest's own planning staff whenever possible. The data were accurate as of 1981 (subsequent changes in data may have occurred) and included information on land classification, characteristics of biological growth, costs and revenues, and available silvicultural prescriptions for forest management.

Not all environmental considerations that affect such resource programs as timber management can be simulated explicitly with a mathematical model such as FORPLAN. Mathematical models require that limiting considerations be quantified either directly, through explicit constraints, or indirectly, through modification of the basic technolog- 
ical coefficient matrix. It is difficult and often impossible to model some considerations-for instance, the likelihood of injunctive lawsuits.

As National Forest land management planning has evolved, several classes of constraints of "environmental" origin commonly included in FORPLAN formulations have also evolved. Their purpose is to limit the latitude of commodity resource utilization in order to meet such noncommodity considerations as water quality, visual quality, endangered species, and human safety. In the Six Rivers case study, four classes of constraints were examined (the specific manner in which these types of constraints are specified varies across regions and national forests):

- Geographic dispersion constraints: For visual and water quality considerations, the geographic concentration of regeneration harvests is limited by various rules of thumb on most western National Forests. For the case forest simulations, no adjacent cutting blocks are allowed within a 10 -year period.

- Old-growth retention: In each timber class, a portion of the old-growth (over rotation age) stands is reserved from cutting, primarily for wildlife considerations.

- Minimum rotation: Rotations are limited to 95 percent of a stand's culmination of mean annual increment. These "biological rotations" are mandated by political and visual management considerations.

- Herbicide availability: The use of chemical agents in site preparation and stand establishment is not allowed, necessitating the use of manual procedures.

Another prevalent and very significant way in which environmental considerations affect timber management is through the withdrawal of land from the timber management land base of a National Forest. A common resolution of conflict between timber management and another allocation of a land area is the assignment to that land of some form of reserved status. Examples include roadless areas designated for further study, wilderness, endangered species critical habitats, archaeological/cultural sites, inner gorges, and the designation "marginal." To examine the impact of land withdrawal, harvest schedules were constructed under two assumed land bases: the "large land base" and the "small land base."

The Six Rivers National Forest consists of more than 957,000 acres. Of that total acreage, 445,000 acres are removed off the top from timber management, 207,000 acres of which are presently designated as forested but unsuitable for timber management. Since 132,000 acres of the 207,000 contain old-growth stands, the timber harvest capability of the forest is clearly sensitive to the procedure that determines suitability. On the bases of three criteria, forest planners have rated certain land as unsuitable: land with stands that cannot regenerate within five years; land providing habitat for endangered species; and land with high slide risk, "inner gorge," or both. The first of these criteria has proved to be the most important in terms of identifying unsuitable lands (personal communication from Robert Zane, Six Rivers National Forest, June 1981). The major point to be made is that even with a large land base, substantial withdrawals of lands from potential timber harvesting have been made due to environmental considerations.

The removal of 445,000 acres leaves 512,000 acres that forest planners classify as "capable, available, and suitable," and that will be referred to in this analysis as the "large land base." On the other extreme-if all acres of conflict were resolved in favor of the nontimber interests - the timber management land base would be reduced from 512,000 acres to about 260,000 . Forest planners refer to these acres that remain free from current conflict as the unlitigated acres, and they will be referred to as the "small land base" in this analysis. 


\begin{tabular}{|c|c|}
\hline & Acres \\
\hline $\begin{array}{l}\text { Total forest } \ldots \ldots \ldots \ldots \ldots \ldots \ldots \ldots \\
\text { minus nonforest, unsuitable, reserved, etc. }\end{array}$ & $\begin{array}{r}957,000 \\
-445,000 \\
\end{array}$ \\
\hline equals large land base. & 512,000 \\
\hline minus wilderness, wild rivers . & $-103,000$ \\
\hline minus other environmentally related withdrawals . . & $-149,000$ \\
\hline equals small land base & 260,000 \\
\hline
\end{tabular}

The difference between the large and small land bases-the acres of potential conflict between timber and nontimber uses-can be divided into two categories: 1) wilderness and wild river exclusions, and 2) all other exclusions.

If all wilderness and wild river land candidate acres (in the entire forest, not just in the large land base) were resolved in favor of exclusionary designations, 264,300 acres would be removed from possible management for other resources.

\begin{tabular}{|c|c|}
\hline Designation & Acres \\
\hline Wilderness (RARE II) & 55,500 \\
\hline Further planning (RARE II) & 59,600 \\
\hline California lawsuit $\ldots \ldots \ldots$ & 60,600 \\
\hline Wild and scenic rivers ..... & 36,700 \\
\hline Blue Creek issue $\ldots \ldots$ & 51,900 \\
\hline Total & 264,300 \\
\hline
\end{tabular}

Not all of the 264,300 acres, however, would have direct impacts on the timber harvest capability of the National Forest if they were withdrawn, because not all of the wilderness and wild river acres fall within the 512,000 acres of the large land base. Of the 264,300 acres, 103,300 acres are currently classed as suitable and available for timber harvesting, and as such are part of the large land base.

\begin{tabular}{|c|c|}
\hline Designation & Acres \\
\hline Wilderness (RARE II) & 22,300 \\
\hline Further planning (RARE II) & 16,700 \\
\hline California lawsuit & 31,100 \\
\hline Wild and scenic rivers. . & 10,700 \\
\hline Blue Creek issue & 22,500 \\
\hline Total & 103,300 \\
\hline
\end{tabular}

Of the other 161,000 acres that could be assigned to wilderness or wild river status, 86,000 acres are classed as nonforest and 75,000 acres are currently classed as forested but unsuitable for timber management, though these acres do contain standing inventories. 
When all other environmentally related land withdrawals (e.g., those related to cultural sites) are made-some 149,000 additional acres of suitable timber harvesting land-a small land base of approximately 260,000 acres remains. The difference between the two land bases consists of 103,000 acres devoted to wilderness and wild rivers and 149,000 acres of other environmentally related land withdrawals.

The final choice in model specification to determine the set of FORPLAN computer runs that make up the case study is the objective function to be maximized. Traditionally, the Forest Service policy has been to maximize the allowable harvest volume subject to a flow constraint (i.e., nondeclining yields). The tradition of biological optimization has been attacked for not fostering economic efficiency. The National Forest Management Act of 1976 requires that economic analysis be part of forest planning (Section 6 of the Act, Section 219 of the ensuing regulations), and current Forest Service directives require that economic objective functions be utilized in the FORPLAN modeling phases of forest planning. With the next iteration of forest plans (to be completed on all National Forests by 1985), the biological (volume) optimization is being joined, if not supplanted, by an objective function of net value maximization. Owing to the current debates over the specification of the value function to be maximized and the appropriate specification of market demand schedules, I have modeled formulations for the traditional policy of volume maximization and two value maximizations:

- Maximize first-decade harvest volume subject to nondeclining yields (NDY).

- Maximize present net worth with horizontal demand (HD) specification. (When a horizontal demand curve [fixed price] is specified, it is necessary to impose a flow constraint in order to preclude unacceptably extreme solutions; e.g., harvesting all or none of the standing inventory in the first decade. For this case study, FORPLAN runs were made with and without a flow constraint. As later discussion of this case reveals, highly variable harvest patterns do result under a fixed price assumption and no flow constraint.)

- Maximize present net benefit with downward-sloping demand (DSD) specification. Since each "policy" or objective function embodies implicit biases, it can be expected that the effects of environmentally induced constraints will differ among them.

With three objective functions, two land bases, and four constraint classes, a set of 96 computer runs would be required in order to model all possible combinations. A subset of 16 runs was initially selected to test the range of possible modeling formulations. These will be referred to as the "core runs" and are described in a later section. Additional runs were also made focusing on individual constraints. Their discussion will follow the analysis of the "core runs."

\section{Modeling price assumptions}

Resource economists agree that some form of economic optimization is preferable to biological optimization, but the precise formulation is a matter of controversy. For the set of FORPLAN computer runs making up the Six Rivers case study, two different price assumptions were modeled, each representing a distinctly contrasting scenario of market structure and behavior.

The first point of controversy concerns the empirical issue of the correct specification of demand: Should it be horizontal or downward-sloping? Having been initially examined by Mead (1966) for the Douglas-fir region, the issue of the market structure for western stumpage is again receiving attention in the context of National Forest plan- 
ning. The present analysis prepared FORPLAN computer runs under both economic formulations-horizontal and downward-sloping demand functions. Proponents of both formulations have published their arguments (Johnson and Schuerman, 1977; Vaux and Zivnuska, 1952; Walker, 1971). The results of this analysis will serve as brackets enclosing what is likely to be the true situation.

The second point of controversy is this question: Should the Forest Service exercise any monopoly power it may possess in order to maximize net revenue to the Federal Treasury? Operationally, maximization of net revenue to the Treasury is accomplished by equating marginal cost with marginal revenue. The alternative is to equate marginal cost with price, thereby maximizing the sum of producers' and consumers' surplus. This "societal" orientation results in foregone revenues to the Federal Treasury, but attains a higher level of social benefit from the consumption of National Forest stumpage. In distilled form, this area of debate centers on the relative merits of present net worth (PNW) maximization versus present net benefit (PNB) maximization as optimization criteria. If a horizontal demand curve were deemed appropriate this would be a moot point, because PNW and PNB maximization would be identical (since marginal revenue would equal price). If a downward-sloping demand curve were chosen, however, the debate between those who view the Forest Service as a revenue maximizer and those who consider it a social maximizer would remain. In the current analysis, the Forest Service will be modeled as social maximizer under downward-sloping demand and as revenue and social maximizer under horizontal demand.

\section{Market area}

This section begins with a brief discussion of the logic and methodology for construction of regional demand curves for National Forest stumpage. Because of the nature of FORPLAN it is the demand for the stumpage from a single National Forest, and not a region, that must be modeled. A procedure is discussed that was employed to bracket (i.e., to approximate) the unknown local demand relationship, using alternative pricing formulations constructed from regional demand information.

This analysis will accept the arguments forwarded by Haynes, Connaughton, and Adams (1981), and assume that, through arbitrage, stumpage prices net of transportation costs and species/ quality differences will equilibrate across the localized markets within a broad geographic region such as the state of California (value differences between species will be factored out of the analysis, using average prices). The implication is that it is then possible to "treat regional average stumpage prices as if they were determined in a regional rather than local markets" (Haynes, Connaughton, and Adams, 1981). As such, regional supply is the aggregation of the supply schedules of the private sector, other public sector, and all 17 National Forests in California.

In 1980, the National Forests contributed 38 percent of the total timber supply offering in California. Accordingly, it is plausible to conclude that the National Forests, in total, can influence regional average stumpage prices (i.e., the regional demand for National Forest stumpage is downward-sloping). Haynes, Connaughton, and Adams (1981) have estimated regional downward-sloping demand curves for California National Forest stumpage. These curves are derived from a regional total demand curve (all ownerships), an assumed private sector regional supply schedule, and an assumption of perfectly inelastic National Forest supply. National Forest demand is then an "excess demand," the demand at each price level not met by the private sector supply. (The 


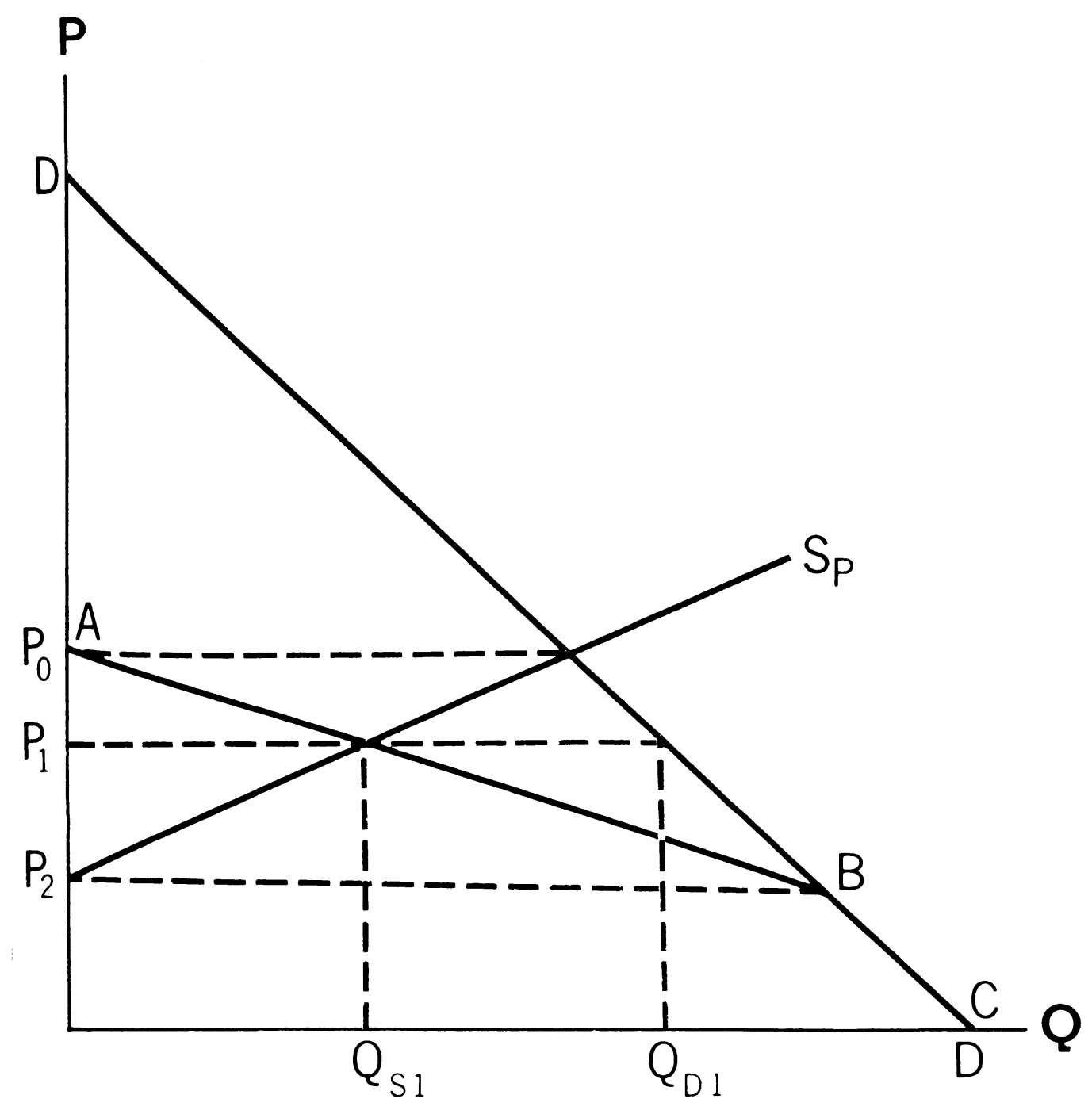

Derivation of regional demand for stumpage from the National Forests.

"other public" sector is assumed away.) For discussion, assume total demand to be DD and private sector supply to be $\mathrm{Sp}$ (see Figure). At $\mathrm{P}_{0}$ the private sector supplies all that is demanded, and the excess demand for National Forest stumpage is zero. At $\mathrm{P}_{1}$ demand is $Q_{D 1}$ and private sector supply offering is $Q_{S_{1}}$. The difference, $Q_{D 1}-Q_{S_{1}}$, is the demand for National Forest stumpage at price $P_{1}$. At price $P_{2}$ and below, private sector supply is zero, and demand for National Forest stumpage equals total demand. Though the resulting National Forest demand schedule $(A B C)$ is kinked, Haynes, Connaughton, and Adams (1981) suggest that segment $B C$ is beyond the range of meaningful price/ output combinations so that a linear formulation is acceptable. For 1980 , the California National Forest demand schedule is:

$$
\begin{aligned}
& \mathrm{P}_{\mathrm{MBF}}=93.06-.161 \mathrm{Q}_{\mathrm{MMCF}} \quad \text { (1967 dollars) } \\
& \mathrm{MBF}=\text { thousand board feet } \\
& \mathrm{MMCF}=\text { million cubic feet }
\end{aligned}
$$


This curve is less steep than total demand because the price elasticity of demand for a subset of all suppliers is greater than for the total. But because of the significant market share attributable to National Forest supply, the demand curve is indeed downwardsloping.

But what is the appropriate specification of demand for the stumpage from a single National Forest? Such a specification is required for FORPLAN modeling. If we accept the notion of regionally determined stumpage price, we can say that the demand elasticities pertinent to a single National Forest are influenced by the supply behavior of the other National Forests in the market region, in addition to the supply behavior of the private sector. Two scenarios representing different assumed behaviors of the "other" National Forests illustrate the implications for demand specification on a single National Forest such as the Six Rivers.

\section{Scenario 1: Multi-forest supply change}

Many regional and national policies and constraints influence the harvest levels of the National Forests. When regional or national policy shifts are implemented, it is plausible to argue, all National Forests within a region will alter their supply offerings (i.e., allowable harvests) in a similar if not identical manner. For instance, the removal of regeneration harvest dispersion constraints could result in some degree of increased harvests from most National Forests. Because of the concomitant nature of supply shifts for many National Forests within a supply region, it is likely that the aggregate supply change would be great enough to influence price significantly, as described by the regional National Forest demand schedule. Thus, when modeling from the perspective of a single National Forest it is appropriate to assume a downward-sloping demand schedule, provided that the concomitant change condition holds. That is to say, when all National Forests change their output in league, but only the output from a single forest is being modeled, it is appropriate to impute a downward-sloping demand curve to that forest. This curve is essentially only a fabrication required for modeling purposes. It serves as a representation of the exogenous supply changes (occurring outside of the modeled "system") which are correlated with endogenous supply shifts and which affect an endogenous variable: price level. Exogenous and concomitant supply shifts lend the impression that the modeled forest has more market power than, in fact, it has.

For this analysis, downward-sloping demand schedules for the Six Rivers National Forest were derived from the regional National Forest demand schedules found in Haynes, Connaughton, and Adams (1981). The central assumption that allowed us to develop local schedules from the regional schedules was that the local price elasticity of demand at the 1980 Six Rivers price/ output combination was equal to the regional price elasticity of demand at the 1980 regional price/output combination. Given a price elasticity and a price/output combination, an exercise in simple algebra derives a local (linear) demand schedule (Appendix A).

The assumption of equal price elasticity of demand at the regional and local levels is plausible in the context of the concomitant change scenario. When all forests change their outputs in league, an output change in one forest is only one component of a regional change. That is, this scenario admits only regional shifts in output that are defined by proportional output changes in each forest. It follows that the perceived price elasticity from the perspective of a single forest should equal the price elasticity on the regional demand curve at the initial price/output combination (before the supply shift). 
Another simple algebraic exercise (Appendix B) shows that when the regional National Forest supply is composed of fixed proportional shares from each forest the price elasticity at the local and regional levels will be identical. While fixed proportions are indeed not the case in the real world, it will be posited that National Forest output changes are correlated closely enough to make the assumption at least plausible. This scenario can be viewed as the most extreme estimate of the price effects of National Forest output changes.

The final issue to address with regard to downward-sloping demand curves for the Six Rivers National Forest is trending over time (i.e., intertemporal shifts of the schedule). Haynes, Connaughton; and Adams (1981) estimate regional National Forest demand curves at 10-year intervals from 1980 to 2030. In FORPLAN modeling, demand curves must be specified for the midpoint of each decade (e.g., 1985, 1995, etc.). Factors for trending the 1980 local demand curve (Table 1) were derived by interpolating the trends in the regional curves (Haynes, Connaughton, and Adams, 1981).

Table 1. SLOPES AND INTERCEPTS FOR SIX RIVERS NATIONAL FOREST TIMBER DEMAND CURVES*

\begin{tabular}{ccc}
\hline Year & Slope & Intercept \\
\hline & & dollars $/ M C F$ \\
1980 & -.0617 & 3,485 \\
1985 & -.0649 & 4,137 \\
1995 & -.0707 & 5,241 \\
2005 & -.0753 & 6,097 \\
2015 & -.0795 & 7,005 \\
2025 & -.0839 & 7,866 \\
\hline
\end{tabular}

* Computed from Haynes, Connaughton, and Adams (1981). Curves are most meaningful in the range around the current price/output combination $\left(P_{\$ / m b f}=303, Q_{m b f}=160,000\right.$ or $P_{\$ / m c f}=1,510, Q_{m c f}=$ $32,000)$.

\section{Scenario 2: Isolated supply change}

At the other extreme, a single forest may alter its output without any associated change in the other forests' outputs within a market supply region. Such a situation might arise from policy changes pertinent to a single forest-policy changes neither regional nor national in nature. For example, the Six Rivers National Forest's output might be affected by litigation specific to it alone.

What is the appropriate price assumption for the situation of isolated forest output change? By definition, the total regional change in National Forest output is equal to the change in output of the forest in question, say the $\mathrm{k}^{\text {th }}$ forest:

$$
\Delta \mathrm{Q}=\Delta \mathrm{q}_{\mathrm{k}} \text {, since } \sum_{\mathrm{i}=1}^{\mathrm{I}} \Delta \mathrm{q}_{\mathrm{i}}=0 \text {, for all } \mathrm{i} \neq \mathrm{k}
$$

where:

$$
\begin{aligned}
& \mathrm{Q}=\text { regional National Forest output } \\
& \mathrm{q}_{\mathrm{i}}=\text { output of the } \mathrm{i}^{\text {th }} \text { National Forest in the region }
\end{aligned}
$$

As such: $\Delta \mathrm{P} / \Delta \mathrm{Q}=\Delta \mathrm{P} / \Delta \mathrm{q}_{\mathrm{k}}$; the slope of the regional demand curve equals the slope of the $\mathrm{k}^{\text {th }}$ forest's demand curve. The regional slopes estimated by Haynes, Connaughton, 
and Adams (1981) can be used at the forest level under the scenario of isolated change. The intercept for the forest level demand curve is found in the same manner (Appendix A).

For this analysis it will be assumed that under the isolated change scenario a forest faces what is essentially an infinitely elastic (horizontal) demand curve. Support for this assumption is found in the estimated regional slopes found in Haynes, Connaughton, and Adams (1981). For California, the slope is -.00027 . Implicit in this case study analysis is the assertion that representing this flat curve with a horizontal line is sufficiently accurate.

The fixed price levels (trended over time) used in this analysis were obtained from Haynes, Connaughton, and Adams (1980). Trends represent real price change relative to 1980 dollars (Table 2).

Table 2. STUMPAGE PRICE LEVELS FOR DOUGLAS-FIR, 1980 TO 2025*

\begin{tabular}{cc}
\hline Year & Price \\
\hline & dollars $/$ mbf (Scribner) \\
1980 & 303 \\
1985 & 378 \\
1995 & 497 \\
2005 & 577 \\
2015 & 685 \\
2025 & 807 \\
\hline
\end{tabular}

* Average annual rates of change used for trending computed from Haynes, Connaughton, and Adams (1980).

The two scenarios represent the extremes in assumed impact of National Forest supply on stumpage price. In the case of output changes isolated to a single National Forest, the assumption of infinite price elasticity (horizontal demand, fixed price) is appropriate. In the case of all National Forests within a region making similar output changes, it is assumed that a more inelastic (downward-sloping) demand curve is appropriate. The elasticity of demand determined by a regional National Forest demand curve is used at the local (single forest) level. In fact, the true price elasticity of demand at the local level probably lies somewhere between these two extremes. The results from modeling under each scenario serve as brackets around the true price and revenue effects.

\section{Costs}

The staff of the Six Rivers National Forest estimated the costs of implementing the silvicultural and managerial tasks that lead to forest growth and timber harvest. The cost coefficients for this case study are identical to those that will be used in the development of the actual Six Rivers National Forest plan (subject to revisions since 1980). Here, as with most linear programming formulations in timber harvest scheduling and forest planning, unit costs are invariable with respect to the ouput level. Using the linear piece-wise approximation strategy that is employed to model downward-sloping demand (and thus a quadratic revenue function), a quadratic cost function (variable marginal costs) can also be modeled. But no empirical information exists that enables such a relationship to be specified. Subsequent generations of modeling formulations may contain this refinement, but the current state of the art-like this case study-assumes unit costs to be insensitive to output. The implication of this assumption is that costs do not, in general, act as a limiting force on output levels in the absence of an explicit budget constraint. Other factors must limit output as long as revenues exceed costs; without these 
additional limiting factors, the linear programming may schedule very high output levels under a situation in which prices are fixed at a higher level than unit costs.

Costs do limit output to the extent that the cost structure of a forest is heterogeneous. As is the situation on the Six Rivers, unit costs may vary across sub-areas (e.g., timber stands) but are fixed with respect to the output level within any one sub-area. Thus, all stands whose unit costs are less than price can be harvested, while those stands whose unit costs exceed price will not be harvested. This characteristic is typical of linear formulations.

Concerning intertemporal changes, only labor-intensive activities are assumed to experience exogenously induced real cost increases (i.e., increases unrelated to endogenous variables such as the output level). These activities include most of the cultural activities such as site preparation, release, precommercial thinning, and sale administration. The real rate of increase in these costs is assumed equal to the annual compound growth rate of real per capita income in California as estimated by the U.S. Water Resources Council (1974) (Table 3). All other cost coefficients, it is assumed, remain constant in real terms-their nominal levels will increase at the same rate as the general price level.

Table 3. ANNUAL INCREASE (PERCENT) IN LABOR-INTENSIVE COST COEFFICIENTS, BY YEAR *

\begin{tabular}{llllll}
\hline & \multicolumn{5}{c}{ Annual percent increase } \\
\cline { 2 - 6 } Starting year & $\mathbf{1 9 8 3}$ & $\mathbf{1 9 9 3}$ & $\mathbf{2 0 0 3}$ & $\mathbf{2 0 1 3}$ & $\mathbf{2 0 2 0}$ \\
\hline 1978 & 3.00 & 2.50 & 2.45 & 2.45 & 2.37 \\
1983 & & 2.25 & 2.32 & 2.35 & 2.29 \\
1993 & & & 2.39 & 2.41 & 2.30 \\
2003 & & & 2.43 & 2.26 \\
2013 & & & & 2.01 \\
\hline
\end{tabular}

- These growth rates should be regarded as high-bound estimates of the rate of growth of labor-intensive cost coefficients.

\section{Discount rate}

The Forest Service is authorized by Forest Service Manual, Section 1971.71, to use a 4 percent real discount rate to measure the opportunity cost of capital (see Roy, Kaiser, and Sessions, 1981, for a discussion of the Forest Service logic supporting the 4 percent rate). To maintain conformity with forest plans, this analysis uses the same rate.

\section{ANALYZING THE CORE RUNS}

The 16 FORPLAN formulations, hereafter referred to as the "core runs," are designed to address the broader questions concerning the impacts of land withdrawals and environmental constraints, as a package, on timber harvest capability under three objective functions. The core runs are defined by meaningful combinations of the following elements (for ease of reference, the letters in italics will be used when describing individual runs): 


\begin{tabular}{|c|c|c|}
\hline Land base & Objective function & $\begin{array}{l}\text { Environmental } \\
\text { constraint level }\end{array}$ \\
\hline$L L$ large $(\$ 10,000$ acres $)$ & $\begin{array}{l}B \text { maximum PNB } \\
\text { with DSD }\end{array}$ & $U$ unconstrained \\
\hline \multirow[t]{2}{*}{$S L$ small $(260,000$ acres $)$} & $\begin{array}{l}W \text { maximum } \mathrm{PNW} \\
\text { with } \mathrm{HD}\end{array}$ & C1 fully constrained \\
\hline & $\begin{array}{c}T \text { maximum first-decade } \\
\text { volume with NDY }\end{array}$ & $\begin{array}{l}\text { C2 fully constrained } \\
\text { plus NDY* }\end{array}$ \\
\hline
\end{tabular}

"The "fully constrained without NDY under volume maximization" runs were not made, since volume maximization has historically been associated with a flow constraint. This omission results in the core run total of 16 .

Thus, $S L, B, U$ refers to the computer run in which PNB is maximized on the small land base with no environmental constraints.

The PNW and PNB runs each have different price assumptions. All PNW runs are associated with the horizontal demand assumption, and all PNB runs contain the downward-sloping demand assumption. As such, PNB and PNW runs for a given land base and constraint combination are not entirely comparable in the traditional sense of competitive solution versus monopoly solution. PNB/DSD is the social maximizing solution under downward-sloping demand and PNW/HD is the revenue and social maximizing solution under horizontal demand. This complication is one of the inadequacies created by a limited computing budget that confines us to consider a subset of the total possible runs. The nomenclature of PNB/DSD and PNW/HD will be used to indicate the price assumption specific to each objective function.

The ultimate purpose of modeling a set of formulations (abstractions of the real system about which information is sought) is to seek inferences based upon comparisons of the solution characteristics of each "run." In order to do so in an orderly and manageable fashion, it is beneficial to identify a group of indices to be the focus of comparison. For this analysis, whose basic focus is on timber harvest capability, indices were identified and classed into two broad groups: physical/biological measures of the timber harvest and production characteristics of each run; and financial measures relating to costs, revenues, and benefits associated with the management activities and production levels of each run. The physical/biological measures are:

- Harvest level, first decade and first five decades

- Long-run sustained-yield level

- Harvest breakdown by species, first decade and first five decades

- Harvest breakdown by logging method, first decade and first five decades

- Harvest breakdown by harvesting system, first decade and first five decades

- Ten-decade harvest pattern

- Fifth-decade growth versus harvest

- Age-class distribution at the planning horizon (16th decade)

- Road-building activity, first decade and first five decades

The financial measures are:

- Total present net worth of the 16-decade plan

- Total present net benefit of the 16-decade plan

- First-decade total costs

- First-decade costs per million cubic feet (MMCF) 
The goal is to be able to identify the basic timber harvest capability of the Six Rivers National Forest-and its attendant physical, biological, and financial characteristicsunder each of the modeling formulations. These measures or indices are designed to provide estimates of that capability. Many of the indices are examined both for the first decade and first five decades. The five-decade level is included because it is the horizon for planning in response to requirements of the Resources Planning Act.

Before delving into the results, a brief discussion of the format for the following tables of coefficients will aid the reader's understanding of them. The computer runs were stratified by objective function and land base. Reference to the legend in the previous section will be helpful in deciphering the coded run names. $B$ runs assume downwardsloping demand, $W$ runs assume horizontal demand, and $T$ runs are priced out with downward-sloping demand. The following comparisons in the text can be more fully understood with careful reference to the tables.

The discussion of each index (e.g., harvest level, present net worth, etc.) is organized around five basic comparisons that are defined by the most meaningful combinations of two land bases and two environmental constraint levels (with and without). These basic comparisons are:

1) with versus without environmental constraints on the large land base $(L L, \ldots, U$ versus $L L, \ldots, C 1)$

2) with versus without environmental constraints on the small land base $(S L, \ldots, U$ versus $S L, \ldots, C 1)$

3) large versus small land base with environmental constraints included ( $L L, \ldots, C 1$ versus $S L, \ldots, C 1)$

4) large versus small land base without environmental constraints included ( $L L, \ldots, U$ versus $S L, \ldots$ )

5) large land base, unconstrained versus small land base, constrained $(L L, \ldots, U$ versus $S L, \ldots, C 1)$

A sixth possible comparison-large land base, constrained versus small land base, unconstrained-is examined in detail in a later section.

The following discussion of these basic comparisons is couched in terms of percentage changes that have been calculated from the pertinent entries in the appropriate tables.

\section{Harvest level}

As should be expected, the first-decade harvest is sensitive to both the land base and the environmental constraints. Going from the large land base to the small land base, the first-decade allowable harvest drops by an average of 39 percent for the unconstrained runs $(L L, \ldots, U$ versus $S L, \ldots, U$, averaged over the three objective functions) and by 16 percent for the constrained runs $(L L, \ldots, C 1$ versus $S L, \ldots, C 1$, averaged over the three objective functions) (Table 4). Alternatively, the imposition of environmental constraints results in an average first-decade allowable harvest drop of 45 percent under the large land base $(L L, \ldots, U$ versus $L L, \ldots, C 1)$ and 25 percent under the small land base $(S L, \ldots, U$ versus $S L, \ldots, C 1)$. It can be inferred that when both environmental constraints and land withdrawals are imposed, the sensitivity of the harvest level to either one is reduced; that is, the effect of one constraint or limit is reduced when additional constraints or limits are imposed.

The joint impact on first-decade harvests of both land withdrawal and constraint imposition is a 34-percent decrease when PNB/DSD is maximized ( $L L, B, U$ versus $S L, B, C 1$ ), 
a 63-percent decrease when PNW/HD is maximized $(L L, W, U$ versus $S L, W, C 1)$, and a 65-percent decrease when harvest volume is maximized ( $L L, T, U$ versus $S L, T, C 2)$.

Similar effects are found on the first-five-decade total harvest level (Table 4, column 2). With land withdrawal, harvest level drops by an average of 49 percent (averaged over the three objective functions) for the unconstrained runs and by an average of 21 percent for the constrained runs. Under constraints, harvest level drops by an average of 36 percent under the large land base. Counterintuitively, the five-decade harvest level increases by an average of 15 percent when the constraints are imposed on the small land base (for $\mathrm{PNB} / \mathrm{DSD}$ and $\mathrm{PNW} / \mathrm{HD}$ ). Though no definitive explanation is possible given the complexities of large-matrix linear programs, this counterintuitive result is best explained by the fact that the first five decades have no special significance in the linear program scheduling process. The solution maximizes the PNW/HD and PNB/DSD over the 16-decacie planning period. The total harvest level for the entire 16-decade period does decrease when the constraints are imposed.

Table 4. PROJECTED HARVEST EFFECTS OF FORPLAN CORE RUNS FOR THE SIX RIVERS NATIONAL FOREST

\begin{tabular}{lccc}
\hline & \multicolumn{3}{c}{ Million cubic feet (MMCF) } \\
\cline { 2 - 4 } Computer run & $\begin{array}{c}\text { First-decade } \\
\text { harvest }\end{array}$ & $\begin{array}{c}\text { First-five-decades } \\
\text { total harvest }\end{array}$ & $\begin{array}{c}\text { Long-run } \\
\text { sustained-yield average }\end{array}$ \\
\hline$L L, B, U$ & 589 & 3,318 & 623 \\
$L L, B, C 1$ & 421 & 2,142 & 350 \\
$L L, B, C 2$ & 350 & 1,749 & 350 \\
$S L, B, U$ & 409 & 1,756 & 312 \\
$S L, B, C 1$ & 387 & 1,857 & 223 \\
$S L, B, C 2$ & 223 & 1,114 & 223 \\
$L L, W, U$ & 1,798 & 2,895 & 617 \\
$L L, W, C 1$ & 698 & 2,083 & 350 \\
$L L, W, C 2$ & 350 & 1,749 & 350 \\
$S L, W, U$ & 1,116 & 1,457 & 308 \\
$S L, W, C 1$ & 666 & 1,798 & 223 \\
$S L, W, C 2$ & 223 & 1,114 & 223 \\
$L L, T, U$ & 631 & 3,156 & 631 \\
$L L, T, C 2$ & 350 & 1,749 & 350 \\
$S L, T, U$ & 317 & 1,586 & 317 \\
$S L, T, C 2$ & 223 & 1,114 & 223 \\
\hline
\end{tabular}

The joint impact on the first-five-decade total harvest of both land base reduction and environmental constraints imposition-in short, the "environmentally induced harvest reduction' - - is 44 percent for $\mathrm{PNB} / \mathrm{DSD}, 38$ percent for $\mathrm{PNW} / \mathrm{HD}$, and 65 percent for volume maximization.

Though not related to the issue of environmentally related effects, harvest levels are sensitive to the objective function that drives the scheduling process. Because of the downward-sloping demand assumption embodied in the PNB/DSD runs, first-decade harvest level is less than that in the PNW/HD runs, which assume a horizontal demand curve. When price falls as output rises, a pecuniary limiting force tied to profit maximization discourages unchecked output expansion-a force that does not exist when price is fixed. Thus, the unconstrained first-decade harvest is 1,798 MMCF with horizontal demand and 589 MMCF with downward-sloping demand. The first-decade harvest 
under volume maximization is lower than that in the PNW/HD runs because the nondeclining yield constraint is also imposed.

\section{Long-run productivity}

In the FORPLAN model, the closest measure of the long-term productivity of a managed forest is the long-run sustained-yield average (LRSYA). LRSYA is the harvest level that can be sustained indefinitely once the beginning (unregulated) standing inventories are liquidated and the sites are restocked with managed second growth stands. Clearly, land withdrawal will reduce the LRSYA for the forest as a management unit, but it will not affect the productivity of acres left in the timber management land base. The effect of land withdrawal on the LRSYA ranges from a 50-percent reduction when the environmental constraints are not imposed to a 36-percent reduction when the constraints are imposed (Table 4, column 3 ). These reductions are identical across all objective functions. Alternatively, the environmental constraints cause a 44-percent drop in LRSYA under the large land base and a 28-percent drop under the small land base. These reductions are nearly identical across all objective functions. The joint effect, or environmentally induced impact (the difference between large land base, unconstrained and small land base, constrained) is a 65-percent drop in LRSYA under all objective functions-a highly significant impact.

As with harvest level, the percentage effects of the environmental constraints are greatest on the large land base. One explanation for this phenomenon is that under the small land base most of the environmentally sensitive acres-those acres for which the constraints would have the greatest effect-are removed. The LRSYA is essentially not influenced by the objective function. A correlated conclusion coupled with the harvest level effects discussed in the previous section is that the objective function significantly influences the rate of liquidation of the standing inventory, but has little influence on the harvest patterns once the forest has been regulated. The time required to attain a regulated forest is much longer under the $\mathrm{PNB} / \mathrm{DSD}$ objective function because of the tendency to slow down the old-growth liquidation rate.

\section{Harvest pattern over time}

The temporal flow of National Forest stumpage has been a major policy issue since the late 1960s. The Douglas-fir Supply Study (USDA Forest Service, 1969) - a widely publicized Forest Service analysis that forecast a falldown in harvest levels at the end of the old-growth liquidation-resulted eventually in the agency's adoption of the nondeclining yield/ even flow policy. The policy implicitly takes the position that a constant flow of stumpage is better than an erratic and declining pattern that is initially higher. Whether that position is appropriate has been the focus of heated debate in the forestry profession. An argument commonly raised against the agency's position is that an erratic private sector supply coupled with a steady National Forest supply will result in a dampened but still fluctuating total supply. To assure steady total supply, the National Forest supply should fluctuate in a manner that counterbalances the private sector fluctuations.

The Forest Service's position has become firmly entrenched as policy, though the $\mathrm{Na}$ tional Forest Management Act regulations provide for departures from it. But even though nondeclining yield/even flow is no longer an unquestioned policy, there is still 
strong sentiment in and out of the agency in support of steady, regular flows of National Forest stumpage. Initially, the rationale offered by the agency for steady flows related to concerns for the stability of small communities dependent on the economic activity associated with harvesting National Forest timber. More recently the nondeclining yield policy has been taken up by environmentalists, primarily because of its effect of holding down current harvest levels. As such, the nondeclining yield debate has become an "environmental issue" and is appropriately addressed in this analysis. Regardless of the legal/administrative requirements for the policy, the temporal steadiness of the harvest pattern remains a criterion by which alternative schedules and plans must be assessed.

Once uneven flow alternatives are admitted, the question must be asked: How much fluctuation is acceptable? No categorical reply is possible, and the ultimate responsibility for identifying acceptability limits lies with USDA and agency policy makers. This analysis can, however, suggest what the harvest pattern will be for various alternatives, and, perhaps, be used to rule out extreme cases that are clearly unacceptable.

The 16 core runs range from strictly even flow to wildly fluctuating patterns (Table 5). The runs can be grouped into three categories, ranging from clearly acceptable (those with even flow patterns) to clearly unacceptable. In this discussion, acceptability pertains only to the temporal harvest pattern and not to other aspects of the schedules. The clearly unacceptable alternatives are those patterns that contain wide disparities in harvest level between adjacent decades and those in which no harvest is scheduled during a decade. The criterion by which interdecadal disparities are judged to be unacceptably wide is neither explicit nor formal. This paper mainly offers a first-cut evaluation of the harvest patterns and identifies those patterns that are likely to be unacceptable to agency planners (who have demonstrated a clear preference for steady flows). In between the two extremes are those patterns that contain harvest fluctuations for which a determina-

Table 5. PROJECTED TEN-DECADE HARVEST PATTERNS OF FORPLAN CORE RUNS FOR THE SIX RIVERS NATIONAL FOREST

\begin{tabular}{|c|c|c|c|c|c|c|c|c|c|c|c|}
\hline \multirow{2}{*}{$\begin{array}{l}\text { Computer } \\
\text { run }\end{array}$} & \multicolumn{10}{|c|}{ Decade } & \multirow{2}{*}{$\begin{array}{l}\text { Acceptability } \\
\text { class }\end{array}$} \\
\hline & 1 & 2 & 3 & 4 & 5 & 6 & 7 & 8 & 9 & 10 & \\
\hline \multicolumn{12}{|c|}{$M M C F$} \\
\hline$L L, B, U$ & 589 & 657 & 691 & 691 & 691 & 839 & 596 & 422 & 562 & 559 & 2 \\
\hline$L L, B, C 1$ & 421 & 455 & 429 & 450 & 387 & 421 & 400 & 445 & 359 & 436 & 2 \\
\hline$L L, B, C 2$ & 350 & 350 & 350 & 350 & 350 & 350 & 350 & 350 & 350 & 350 & 1 \\
\hline$S L, B, U$ & 409 & 421 & 387 & 320 & 219 & 395 & 329 & 316 & 252 & 186 & 2 \\
\hline$S L, B, C 1$ & 387 & 405 & 387 & 354 & 324 & 253 & 84 & 0 & 421 & 276 & 3 \\
\hline$S L, B, C 2$ & 223 & 223 & 223 & 223 & 223 & 223 & 223 & 223 & 223 & 223 & 1 \\
\hline$L L, W, U$ & 1,798 & 896 & 20 & 124 & \multicolumn{2}{|c|}{572,407} & 259 & 0 & 186 & 15 & 3 \\
\hline$L L, W, C 1$ & 698 & 273 & 253 & 681 & 178 & 330 & 674 & 218 & 257 & 589 & 3 \\
\hline$L L, W, C 2$ & 350 & 350 & 350 & 350 & 350 & 350 & 350 & 350 & 350 & 350 & 1 \\
\hline$S L, W, U$ & 1,115 & 232 & 6 & 80 & 25 & 941 & 121 & 18 & 372 & 201 & 3 \\
\hline$S L, W, C 1$ & 666 & 254 & 185 & 566 & 127 & 232 & 94 & 0 & 0 & 564 & 3 \\
\hline$S L, W, C 2$ & 223 & 223 & 223 & 223 & 223 & 223 & 223 & 223 & 223 & 223 & 1 \\
\hline$L L, T, U$ & 631 & 631 & 631 & 631 & 631 & 631 & 631 & 631 & 631 & 631 & 1 \\
\hline$L L, T, C 2$ & 350 & 350 & 350 & 350 & 350 & 350 & 350 & 350 & 350 & 350 & 1 \\
\hline$S L, T, U$ & 317 & 317 & 317 & 317 & 317 & 317 & 317 & 317 & 317 & 317 & 1 \\
\hline$S L, T, C 2$ & 223 & 223 & 223 & 223 & 223 & 223 & 223 & 223 & 223 & 223 & 1 \\
\hline
\end{tabular}


tion of acceptability (or unacceptability) is even more subjective.

The data lead to some general conclusions (Table 5). First, the "maximize PNW/HD without NDY" runs result in generally unacceptable flow patterns marked by a rapid liquidation of the standing old-growth inventory. This is explained by the fixed-price assumption. Conversely, the "maximize PNB/DSD without NDY" runs result in much steadier flows because of the limiting mechanism induced by the downward-sloping demand curve. Under a downward-sloping demand scenario the need for an explicit flow constraint such as NDY is reduced; physical constraints can be replaced by pecuniary constraints. Finally, the environmental constraints and land base have no clear relationship to harvest flow acceptability. The unacceptable runs contain both large and small land bases and both constrained and unconstrained specifications.

An important issue to address is the cost of assuring harvest flow acceptability. In this case study, the focus is on the characteristics of the runs that contain the NDY constraint in contrast to those that do not. The NDY constraint most directly influences the oldgrowth liquidation rate represented, for instance, by the first-decade harvest level. The first-decade harvest is, in fact, the single most important characteristic of each schedule, for reasons beyond its correlation with the rate of old-growth liquidation. It is the one index by which analysts in and out of the agency most frequently appraise the worth or attractiveness of alternative harvest schedules.

The first-decade harvest level is significantly affected by the NDY constraint (Table 6). The acceptable runs (those with NDY) have an average first-decade harvest level 37 percent below the questionable runs and 66 percent below the unacceptable runs. (Others have investigated the impacts of the NDY constraint. Berck [1979] estimated a 45-percent drop due to NDY.) These harvest "costs" of NDY can be translated into monetary terms, but the magnitude and sign (+ or - ) of the monetary costs depend on which price assumption is made. That is to say, the reduction in first-decade harvest reduces present net revenue under a horizontal demand specification, but results in higher present net revenue under a downward-sloping specification.

\section{Table 6. PROJECTED FIRST-DECADE IMPACT OF ASSURING HARVEST FLOW ACCEPTABILITY BY SPECIFYING NONDECLINING YIELDS (NDY), FORPLAN CORE RUNS FOR THE SIX RIVERS NATIONAL FOREST}

\begin{tabular}{lc}
\hline & Average first-decade harvest (MMCF) \\
\hline Acceptable (even flow, with NDY) & 333 \\
Questionable (moderately erratic, without NDY) & 529 \\
. Unacceptable (highly erratic, without NDY) & 991 \\
\hline
\end{tabular}

The NDY constraint does not affect the long-run productivity of the forest as represented by the long-run sustained-yield average (Table 4). Indeed, in the long run the forest is fully regulated and a constant flow pattern is a natural outcome.

There are many considerations and policies that must be addressed and met, to some degree, in a single implemented forest plan and harvest schedule. It is up to policy makers to determine whether the costs of satisfying the desire for harvest flow stability are justifiable in light of other goals and considerations. 


\section{Forest growth}

Because of its obvious correlation with subsequent yields, forest growth is a basic consideration and concern in forest management. The goal of the Forest Service is to assure that by the year 2030 (the RPA planning horizon) growth equals or exceeds removals on all National Forests (P.L.96-514, Section 310 numbers 3 and 4 as interpreted in the Forest Service Chief's 1910 memo of March 30, 1981). Table 7 shows which of the core runs could meet the growth goal if the schedules were followed for the next 50 years.

Table 7. PROJECTED FIFTH-DECADE GROWTH GOAL ATTAINMENT OF FORPLAN CORE RUNS FOR THE SIX RIVERS NATIONAL FOREST

\begin{tabular}{lc|lc}
\hline Computer run & Attainment? & Computer run & Attainment? \\
\hline$L L, B, U$ & No & $S L, B, U$ & Yes \\
$L L, B, C 1$ & No & $S L, B, C 1$ & No \\
$L L, B, C 2$ & No & $S L, B, C 2$ & No \\
$L L, W, U$ & Yes & $S L, W, U$ & Yes \\
$L L, W, C 1$ & Yes & $S L, W, C 1$ & Yes \\
$L L, W, C 2$ & No & $S L, W, C 2$ & Yes \\
$L L, T, U$ & Yes & $S L, T, U$ & Yes \\
$L L, T, C 2$ & No & $S L, T, C 2$ & Yes \\
\hline
\end{tabular}

The most significant influence on achievement of the growth goal is the objective function. The "maximize PNB/DSD" runs, with one exception, fail to meet the growth goal. But identifying the reason for this result leads to a more basic conclusion: that the underlying factor influencing growth goal attainment is the harvest rate of the oldgrowth inventories. ("Maximize PNB/DSD" runs generally have a slow liquidation rate for the old-growth.) The relationship between the constraints and growth goal attainment is weaker. In about 60 percent of the cases (constrained versus unconstrained comparisons), the imposition of the environmental and NDY constraints prevents attainment of the growth goal. Since the harvest rate is lowered by both specifying "maximize PNB/DSD" and by imposing the constraints, growth goal attainment appears to be enhanced by the increase of the liquidation rate of old-growth inventories. This result should be expected intuitively, since liquidating the older, slower-growing stands allows the sites to be restocked with younger, faster-growing stands.

\section{Silvicultural and management characteristics}

For the harvest schedules produced by models such as FORPLAN to be in any sense optimal, they must be implemented in the manner prescribed by the linear programming solution. The manner of implementation involves aspects such as the prescribed location, species composition, harvesting system, logging method, and attendant roadbuilding requirements. These aspects are detailed in a FORPLAN solution and can serve as additional indices with which to assess and compare alternative harvest schedules. They can also serve as additional bases for describing the effects of environmentally related constraints on the timber management program.

Looking first at the species composition of the harvest, we can see that land withdrawals generally resulted in a greater concentration of Douglas-fir (Table 8). Though not so distinct an effect, the imposition of environmental constraints $(C 1)$ also resulted in a 
general increase in the concentration of Douglas-fir. Since the species composition of the harvest is not generally an environmental concern, these results suggest no significant implication. Of greater interest is the fact that the NDY constraint resulted in a major shift away from Douglas-fir harvests in the first decade. It is likely that a shift in harvest composition such that only 7 percent of the volume is Douglas-fir (under $S L, B, C 2$ and $S L, W, C 2$ ) would be unacceptable from the standpoint of the supply requirements of local and regional timber processors geared to Douglas-fir lumber markets.

Table 8. PROJECTED SPECIES CONCENTRATION FOR DOUGLAS-FIR, FORPLAN CORE RUNS FOR THE SIX RIVERS NATIONAL FOREST, FIRST DECADE AND FIRST FIVE DECADES

\begin{tabular}{lcc}
\hline & \multicolumn{2}{c}{ Percentage of total harvest } \\
\cline { 2 - 3 } Computer run & First decade & First five decades \\
\hline$L L, B, U$ & 73 & 68 \\
$L L, B, C 1$ & 76 & 63 \\
$L L, B, C 2$ & 24 & 57 \\
$S L, B, U$ & 92 & 73 \\
$S L, B, C 1$ & 100 & 72 \\
$S L, B, C 2$ & 7 & 58 \\
$L L, W, U$ & 66 & 68 \\
$L L, W, C 1$ & 57 & 64 \\
$L L, W, C 2$ & 24 & 62 \\
$S L, W, U$ & 68 & 71 \\
$S L, W, C 1$ & 62 & 74 \\
$S L, W, C 2$ & 7 & 63 \\
$L L, T, U$ & 89 & 65 \\
$L L, T, C 2$ & 51 & 65 \\
$S L, T, U$ & 93 & 56 \\
$S L, T, C 2$ & 58 & 42 \\
\hline
\end{tabular}

Table 9. PROJECTED DEGREE OF CLEARCUT HARVESTING, FORPLAN CORE RUNS FOR THE SIX RIVERS NATIONAL FOREST, FIRST DECADE AND FIRST FIVE DECADES

\begin{tabular}{lcc}
\hline & \multicolumn{2}{c}{ Percentage of total harvest } \\
\cline { 2 - 3 } Computer run & First decade & First five decades \\
\hline$L L, B, U$ & 29 & 25 \\
$L L, B, C 1$ & 76 & 54 \\
$L L, B, C 2$ & 100 & 96 \\
$S L, B, U$ & 85 & 74 \\
$S L, B, C 1$ & 100 & 95 \\
$S L, B, C 2$ & 78 & 75 \\
$L L, W, U$ & 31 & 24 \\
$L L, W, C 1$ & 86 & 67 \\
$L L, W, C 2$ & 100 & 97 \\
$S L, W, U$ & 95 & 89 \\
$S L, W, C 1$ & 87 & 79 \\
$S L, W, C 2$ & 100 & 96 \\
$L L, T, U$ & 23 & 5 \\
$L L, T, C 2$ & 77 & 68 \\
$S L, T, U$ & 80 & 69 \\
$S L, T, C 2$ & 84 & 53 \\
\hline
\end{tabular}


The manner in which trees are harvested and removed from the forest site is a major environmental concern. Soil erosion, water quality, wildlife habitat, and the aesthetic character of a forest are all affected by the manner in which trees are converted to logs at the roadside. Generally speaking, the environmentalist looks upon clearcutting and conventional (tractor) logging with disfavor. But environmentally related land withdrawal and imposition of constraints results paradoxically in an increase in the percentage of the harvest scheduled for clearcutting (Table 9). The "environmentally related effect" raises the clearcutting level from 28 percent to 90 percent of the first-decade harvest (averaged over all objective functions). The five-decade clearcutting level rises from an average of 18 percent to 76 percent. In absolute terms rather than percentage levels, the acres clearcut remain about the same after constraints are imposed and the land base reduced (Table 10). The percentage increase in clearcutting results from a reduction of total harvest with no associated reduction of the amount clearcut.

Table 10. PROJECTED TOTAL ACRES CLEARCUT, FORPLAN CORE RUNS FOR THE SIX RIVERS NATIONAL FOREST

\begin{tabular}{lcc}
\hline Computer run & First decade & First five decades \\
\hline$L L, B, U$ & 26,000 & 114,000 \\
$L L, B, C 1$ & 39,000 & 139,000 \\
$L L, B, C 2$ & 37,000 & 184,000 \\
$S L, B, U$ & 55,000 & 199,000 \\
$S L, B, C 1$ & 44,000 & 184,000 \\
$S L, B, C 2$ & 23,000 & 115,000 \\
$L L, W, U$ & 85,000 & 113,000 \\
$L L, W, C 1$ & 70,000 & 176,000 \\
$L L, W, C 2$ & 37,000 & 202,000 \\
$S L, W, U$ & 156,000 & 201,000 \\
$S L, W, C 1$ & 68,000 & 194,000 \\
$S L, W, C 2$ & 23,000 & 123,000 \\
$L L, T, U$ & 24,000 & 25,000 \\
$L L, T, C 2$ & 34,000 & 136,000 \\
$S L, T, U$ & 74,000 & 167,000 \\
$S L, T, C 2$ & 30,000 & 81,000 \\
\hline
\end{tabular}

The environmentally related effect on logging method is not so easily distinguished (Table 11). Under PNW/HD and volume maximization, first-decade tractor logging increases (it decreases under PNB/DSD maximization). Over five decades, tractor logging increases under PNB/DSD and PNW/HD maximization. The clearest effect is that the addition of the NDY constraint to the environmental constraints increases the amount of tractor logging in all cases. The general inference to be made is that with land withdrawal and constraint imposition most of the steep-slope sites are not available for harvest. As such, the need for nonconventional logging methods is reduced.

Road construction exerts the single greatest impact on the physical and visual forest environment. Furthermore, a state of roadlessness has assumed great value to environmentalists, perhaps symbolically or as a strong front line against subsequent forest resource utilization. National Forest road building occurs primarily to support harvesting activities, so factors determining the extent of road building operate through their effects on the harvest level. As expected, the environmentally related reduction in firstdecade road building ranges from 3 percent for PNB/DSD maximization to 84 percent 
for volume maximization (Table 12). Five-decade road-building reduction ranges from 41 percent for $\mathrm{PNB} / \mathrm{DSD}$ maximization to 59 percent for volume maximization. Because of its effect on the liquidation rate, the NDY constraint results in the most significant reduction in first-decade and five-decade road building. This relationship by itself would make environmentalists favor the NDY constraint.

Table 11. PROJECTED DEGREE OF CONVENTIONAL LOGGING, FORPLAN CORE RUNS FOR THE SIX RIVERS NATIONAL FOREST, FIRST DECADE AND FIRST FIVE DECADES

\begin{tabular}{lcc}
\hline & \multicolumn{2}{c}{ Percentage of total logging } \\
\cline { 2 - 3 } Computer run & First decade & First five decades \\
\hline$L L, B, U$ & 100 & 60 \\
$L L, B, C 1$ & 90 & 77 \\
$L L, B, C 2$ & 100 & 82 \\
$S L, B, U$ & 98 & 74 \\
$S L, B, C 1$ & 87 & 73 \\
$S L, B, C 2$ & 100 & 83 \\
$L L, W, U$ & 71 & 70 \\
$L L, W, C 1$ & 82 & 75 \\
$L L, W, C 2$ & 100 & 97 \\
$S L, W, U$ & 78 & 74 \\
$S L, W, C 1$ & 82 & 74 \\
$S L, W, C 2$ & 100 & 97 \\
$L L, T, U$ & 72 & 71 \\
$L L, T, C 2$ & 53 & 70 \\
$S L, T, U$ & 86 & 79 \\
$S L, T, C 2$ & 76 & 67 \\
\hline
\end{tabular}

Table 12. PROJECTED MILES OF ROAD TO BE CONSTRUCTED, FORPLAN CORE RUNS FOR THE SIX RIVERS NATIONAL FOREST, FIRST DECADE AND FIRST FIVE DECADES

\begin{tabular}{lcc}
\hline & & Miles \\
\cline { 2 - 3 } Computer run & First decade & First five decades \\
\hline$L L, B, U$ & 474 & 1,983 \\
$L L, B, C 1$ & 537 & 1,195 \\
$L L, B, C 2$ & 130 & 804 \\
$S L, B, U$ & 570 & 1,164 \\
$S L, B, C 1$ & 460 & 1,169 \\
$S L, B, C 2$ & 73 & 493 \\
$L L, W, U$ & 1,656 & 2,009 \\
$L L, W, C 1$ & 633 & 1,181 \\
$L L, W, C 2$ & 130 & 890 \\
$S L, W, U$ & 785 & 1,045 \\
$S L, W, C 1$ & 571 & 1,157 \\
$S L, W, C 2$ & 73 & 536 \\
$L L, T, U$ & 1,506 & 2,188 \\
$L L, T, C 2$ & 556 & 1,217 \\
$S L, T, U$ & 741 & 1,125 \\
$S L, T, C 2$ & 243 & 890 \\
\hline
\end{tabular}




\section{Future structure of the managed forest}

A final physical/biological criterion by which alternative harvest schedules can be assessed and compared is the future forest structure that would result from the implementation of each schedule. In current National Forest land management planning, the planning horizon is usually 16 decades. Outputs and activities are scheduled over that time period primarily as a check to ensure that the general direction of short-term actions is acceptable. There is a wide range in the 16th-decade age class distribution resulting from the core runs (Table 13). In general, the unconstrained runs result in a managed forest that could almost be labeled a tree farm by contemporary standards for forests in the western United States. The forest would be managed on rotations as short as 50 years. Whether or not this forest structure is acceptable for a National Forest is, once again, a question to be addressed by policy makers, aided by public input. Short rotations pertain only to the managed portion of the National Forest (i.e., those acres subjected to timber harvest over the 16-decade period). Nonharvest areas in the Six Rivers National Forest comprise 450,000 acres under the large land base and 700,000 under the small land base. The trees on those lands are simply 160 years older at the planning horizon. Under either land base, the tree farm character pertains only to a portion of the overall forest.

Table 13. PROJECTED VOLUME OF SUITABLE, AVAILABLE, AND CAPABLE TIMBER, FORPLAN CORE RUNS FOR THE SIX RIVERS NATIONAL FOREST, CLASSIFIED BY AGE CLASS AT THE END OF THE SIXTEENTH DECADE

\begin{tabular}{|c|c|c|c|c|c|c|c|c|c|c|c|c|c|c|c|}
\hline \multirow[b]{2}{*}{ Computer run } & \multicolumn{15}{|c|}{ Age class (decade) } \\
\hline & 2 & 3 & 4 & 5 & 6 & 7 & 8 & 9 & 10 & 11 & 12 & 13 & 14 & 15 & $16+$ \\
\hline & \multicolumn{15}{|c|}{$M M C F$} \\
\hline$L L, B, U$ & 19 & 338 & 366 & 573 & & & 10 & & & & & & & & \\
\hline$L L, B, C 1$ & & 11 & 188 & 147 & 199 & 275 & 217 & 270 & & & & & & & \\
\hline$L L, B, C 2$ & & 8 & 114 & 75 & 170 & 161 & 233 & 261 & 289 & 125 & 269 & 202 & 32 & & 23 \\
\hline$S L, B, U$ & 8 & 123 & 229 & 393 & 9 & & & & & & & & & & \\
\hline$S L, B, C 1$ & & 9 & 151 & 94 & 193 & 341 & & & & & & & & & \\
\hline$S L, B, C 2$ & & 5 & 49 & 91 & 89 & 102 & 148 & 166 & 205 & 98 & 135 & 136 & 3 & & 18 \\
\hline$L L, W, U$ & 1 & 96 & 78 & 248 & 521 & & & & & & & & & & \\
\hline$L L, W, C 1$ & & 5 & 303 & 128 & 137 & 373 & 184 & 195 & & & & & & & 1 \\
\hline$L L, W, C 2$ & & 8 & 125 & 104 & 166 & 152 & 191 & 249 & 306 & 287 & 372 & & 36 & & 5 \\
\hline$S L, W, U$ & & 47 & 41 & 74 & 43 & 167 & 277 & & & & & & & & 1 \\
\hline$S L, W, C 1$ & & 3 & 225 & 60 & 138 & 457 & & & & & & & & & \\
\hline$S L, W, C 2$ & & 5 & 79 & 60 & 109 & 91 & 105 & 173 & 198 & 239 & 174 & 19 & 3 & & 3 \\
\hline$L L, T, U$ & 23 & 161 & 390 & 449 & 378 & 199 & 573 & 102 & & & & & & & \\
\hline$L L, T, C 2$ & & 6 & 102 & 130 & 158 & 187 & 190 & 223 & 338 & 67 & 250 & 235 & 89 & 86 & 27 \\
\hline$S L, T, U$ & 7 & 72 & 164 & 234 & 15 & 249 & 280 & 184 & & & & & & & \\
\hline$S L, T, C 2$ & & 5 & 50 & 73 & 101 & 137 & 129 & 121 & 119 & 110 & 79 & 239 & & & 185 \\
\hline
\end{tabular}


One of the environmental constraints is a minimum rotation requirement. Rotations are limited to 95 percent of the culmination of the mean annual increment for a stand not treated by thinning - a period of about 90 to 100 years for the Six Rivers National Forest. This constraint (in conjunction with the other environmental constraints) results in an older managed forest at the 16th decade. Not surprisingly, the forest is managed at the minimum rotation. Once again, the NDY constraint results in significant differences from the runs without the flow constraint. The 16th-decade managed forest is of a much older general age level for the NDY runs. The primary explanation for this is that the NDY constraint slows the liquidation rate so much that, at the 16th decade, there is a portion of the first-decade standing inventory that still has not been liquidated.

Another basis of evaluation is a comparison of the 16th-decade acres per age class distribution for each run with the age class distribution for a fully regulated (managed) forest. Following the approach described by Davis (1954), the proportion of each age class to the total area, in percent, was computed for each run (Table 14). The next step is to compare these proportional distributions with the desired distribution. Two rotations are pertinent in determining the desired age class distribution: for the unconstrained runs, the rotation is 60 years, the economic optimum (all unconstrained runs should be compared with the structure of a fully regulated forest on a 60-year rotation); for the constrained runs-which include a minimum rotation requirement-the basis of comparison is a regulated forest under a 100-year rotation. A fully regulated forest under a 60 -year rotation would have 16.66 percent of the total area in each class. Under a 100 -year rotation, each age class would contain 10 percent of the total area. The unconstrained runs should be compared with the 16.66 percent standard and the constrained runs compared with the 10 percent standard (Table 14).

Through its effect of slowing the old-growth liquidation rate, the NDY constraint acts as an obstacle to the expeditious attainment of a fully regulated forest (Table 14). The NDY runs ( $C 2$ runs) consistently show the greatest disparity from the desired age class distribution. Though not so pronounced, the $C 1$ runs (environmental constraints only) are characterized by an excess of acreage in the over-rotation age classes. 


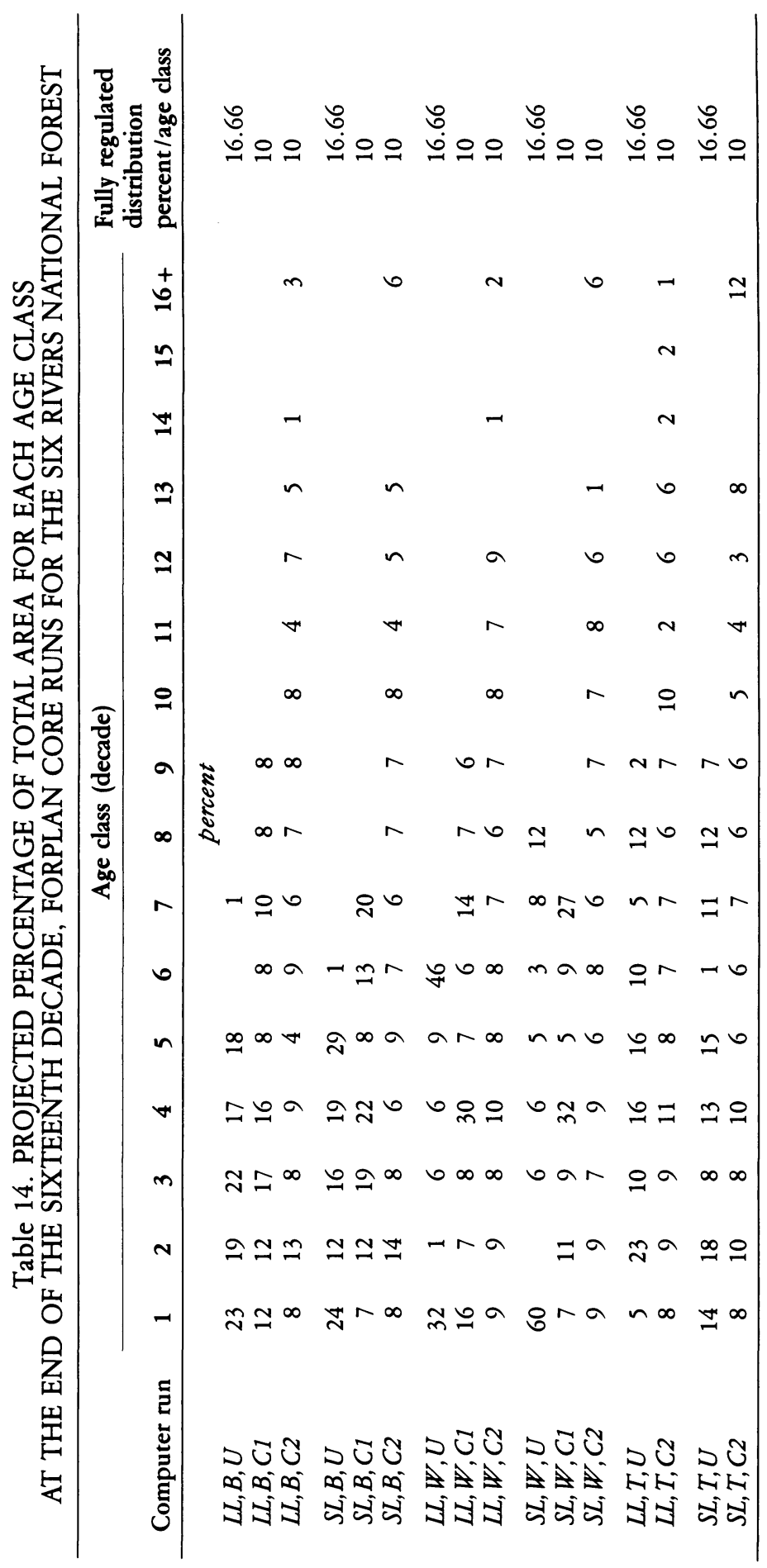




\section{Present net worth}

In the current political climate favoring fiscal austerity and a balanced federal budget, the costs and revenues associated with federal programs such as the management of the National Forests take on added significance. Harvest schedules and forest plans that generate more revenues than costs must be viewed with greater interest. But the revenue/ cost balance of a harvest schedule depends not only on the prescribed activities and associated outputs, but also on the assumptions about prices and unit costs. The net revenues received into the Federal Treasury differ greatly with differing price assumptions (Table 15). When price is assumed to be insensitive to the output level, the estimated net revenue is much greater than when a downward-sloping demand curve is assumed. Furthermore, the net revenues generated depend upon the objective function that is maximized, to the extent that harvest schedules differ across objective functions. And most importantly to the focus of this case analysis, the economic costs (both direct and opportunity) of meeting environmental considerations depend on the price assumptions.

Table 15. PROJECTED PRESENT NET WORTH AND PRESENT NET BENEFIT OVER SIXTEEN DECADES, FORPLAN CORE RUNS FOR THE SIX RIVERS NATIONAL FOREST

\begin{tabular}{lcc}
\hline & \multicolumn{2}{c}{ Million dollars } \\
\cline { 2 - 3 } Computer run & Present net worth & Present net benefit \\
\hline$L L, B, U$ & 1,158 & 4,794 \\
$L L, B, C 1$ & 2,383 & 3,916 \\
$L L, B, C 2$ & 2,576 & 3,597 \\
$S L, B, U$ & 2,242 & 3,462 \\
$S L, B, C 1$ & 2,114 & 3,197 \\
$S L, B, C 2$ & 2,113 & 2,527 \\
$L L, W, U$ & 4,126 & 4,126 \\
$L L, W, C 1$ & 2,453 & 2,453 \\
$L L, W, C 2$ & 2,199 & 2,199 \\
$S L, W, U$ & 2,131 & 2,131 \\
$S L, W, C 1$ & 1,885 & 1,885 \\
$S L, W, C 2$ & 1,403 & 1,403 \\
$L L, T, U$ & 1,046 & 4,254 \\
$L L, T, C 2$ & 2,497 & 3,518 \\
$S L, T, U$ & 2,232 & 3,059 \\
$S L, T, C 2$ & 2,061 & 2,474 \\
\hline
\end{tabular}

Under the assumption of downward-sloping demand, net revenue is maximized at an output level below that which would be obtained under the maximize PNB runs. That is to say, due to its market power the Forest Service would maximize net revenues by acting as a monopolist, restricting output. Under the PNB/DSD and volume runs, the environmentally related harvest reductions are forcing the Forest Service in effect to act as a monopolist. By restricting output for reasons totally unrelated to net revenue maximization, the net revenue can be increased. When PNB/DSD is maximized, the environmentally induced harvest reductions result in an 82-percent increase in net revenues. When harvest volume is maximized, a 97-percent increase in net revenues results from the environmentally related harvest reductions. So rather than incurring a "cost," environmental considerations enhance the net revenue character of the schedule-under downward-sloping demand. 
If a fixed price is assumed (horizontal demand), strikingly different conclusions are reached. Environmentally induced harvest reductions result in a 47-percent decrease in net revenues (PNW maximization). Here, revenue is a linear transformation of harvest level, and the environmental constraints result in a diametrically opposite effect on revenues.

The costs and revenues being discussed in this section are somewhat narrowly defined. Revenues are strictly related to stumpage prices, and purchaser-built road expenditures are netted out. Costs are strictly related to the activities and overhead associated with management prescriptions. The capital costs of holding wood volume on the stump are not considered in the analysis.

\section{Present net benefit}

Net benefit is a measure that incorporates both returns to producers and benefits to consumers. Accepting the compensation principle, output/consumption levels derived through PNB maximization are superior to output/consumption levels derived through PNW maximization. The gains in consumer benefits are greater than the losses in producer returns. So if concerns for the maximization of benefits from the production and consumption of National Forest timber outweigh concerns for fiscal efficiency, PNB is an appropriate criterion with which to compare and assess alternative harvest plans and schedules. It is also an appropriate measure of the costs of meeting environmental considerations. However, because of distributional considerations this type of Kaldor/Hicks welfare superiority is a very limited substitute for social preferability. For instance, redistributing profits away from one segment of the economy by increasing government profits (returns to the Treasury) may be deemed counterproductive from an overall social welfare point of view, as perceived by policy makers and the public-or it may not be.

In contrast to their combined impact on present net worth, environmentally related land withdrawal and constraint imposition result in a decrease in PNB under all objective functions and price assumptions (Table 15). When environmental considerations are met, 16-decade present net benefit is reduced by 33 percent under "maximize $\mathrm{PNB} / \mathrm{DSD}$," by 54 percent under "maximize PNW/HD," and by 42 percent under "maximize volume." It is up to policy makers and the public to judge whether or not the gains from meeting environmental goals are justified in the face of these costs.

\section{First-decade financial indices}

Again, because of political pressures to reduce the size of the federal budget in the near term, the first-decade cost level of alternative schedules may be of increasing interest to policy makers. Costs correlate closely with output level, as is expected (Table 16). On the basis of minimizing the costs of National Forest management, lower output levels (and associated activities) make for more attractive alternatives. First-decade timberrelated costs necessary to produce 223 million cubic feet of harvest are $\$ 58$ million. To truly minimize management costs, the National Forests' management should simply be reduced to a custodial management level with no commodity production. From the standpoint of cost reduction, meeting environmental goals is attractive since harvest levels are reduced. 
There is no discernible relationship between unit costs (first-decade costs divided by first-decade output) and the attainment of environmental goals (Table 16). Furthermore, there is no apparent relationship between output level and unit costs. The most cogent explanation is that the production process differs at each output level. The extent of road building, method of harvest and logging, extent of thinning, and use of site release prescriptions all differ in each run. A comparison of runs grouped by objective function reveals one expected result: the unit costs for the volume maximization runs are higher, since costs are not entered as a penalty in the objective function. As such, the "maximize volume" solutions include prescriptions that are more costly than the mix of prescriptions scheduled when costs are "paid for" in the objective function.

Table 16. PROJECTED FIRST-DECADE TOTAL COST AND COST PER MILLION CUBIC FEET (MMCF), FORPLAN CORE RUNS FOR THE SIX RIVERS NATIONAL FOREST

\begin{tabular}{lcc}
\hline & \multicolumn{2}{c}{ Million dollars } \\
\cline { 2 - 3 } Computer run & Total cost & Cost per MMCF \\
\hline$L L, B, U$ & 219 & .372 \\
$L L, B, C 1$ & 161 & .382 \\
$L L, B, C 2$ & 92 & .263 \\
$S L, B, U$ & 175 & .428 \\
$S L, B, C 1$ & 155 & .400 \\
$S L, B, C 2$ & 58 & .260 \\
$L L, W, U$ & 723 & .402 \\
$L L, W, C 1$ & 234 & .335 \\
$L L, W, C 2$ & 92 & .263 \\
$S L, W, U$ & 354 & .317 \\
$S L, W, C 1$ & 242 & .363 \\
$S L, W, C 2$ & 58 & .260 \\
$L L, T, U$ & 411 & .651 \\
$L L, T, C 2$ & 144 & .411 \\
$S L, T, U$ & 191 & .603 \\
$S L, T, C 2$ & 82 & .368 \\
\hline
\end{tabular}

\section{DISPERSION AND HERBICIDE CONSTRAINTS}

Another set of computer runs was made to identify the specific effects of dispersion and herbicide constraints. Because the bases of comparison are the fully constrained runs under PNW/HD and PNB/DSD maximization, the question to be answered is: What would be the impacts on the harvest schedule and attendant indices if the dispersion or herbicide constraints were removed? Each constraint was examined under two objective functions, and as such, two price assumptions.

\section{Dispersion}

In the absence of any limitation, a linear program may (and, in fact, is likely to) inadvertently schedule harvesting activities in a geographically and temporally concentrated manner. Such harvest patterns are efficient with regard to the specific value function being optimized. But these schedules are likely to be deemed unacceptable accord- 
ing to other criteria such as visual and water quality. To limit the extent of deleterious impacts on visual and water resources, forest planning teams commonly specify explicit constraints on the geographic intensity of harvesting activities. The manner in which dispersion is specified varies between forests, some specifications being more restrictive than others. For the case study runs, clearcuts and shelterwood harvests were constrained so that no adjacent land units could be regeneration-harvested in the same decade. In some forest zones, a requirement was imposed that for every acre "altered," seven acres must remain unaltered.

Imposition of these constraints compromises the objective function, because the allowable harvest declines-a trade-off exists between timber harvest and environmental quality goals. By deleting the dispersion constraints and comparing the resulting schedule with the fully constrained schedule (but without a nondeclining-yield requirement), the trade-off relationship can be isolated (Table 17). Compare, for example, column 1 to column 2 in Table 17 for the impacts under "maximize PNB with downward-sloping demand," and column 4 to column 5 for the impacts under "maximize PNW with horizontal demand."

Table 17. PROJECTED EFFECTS OF DELETING THE DISPERSION AND HERBICIDE CONSTRAINTS, FORPLAN CORE RUNS FOR THE SIX RIVERS NATIONAL FOREST

\begin{tabular}{|c|c|c|c|c|c|c|}
\hline & \multicolumn{3}{|c|}{ Maximize PNB with DSD } & \multicolumn{3}{|c|}{ Maximize PNW with HD } \\
\hline & $\begin{array}{c}\text { Fully } \\
\text { constrained } \\
\text { (1) }\end{array}$ & $\begin{array}{c}\text { Delete } \\
\text { dispersion } \\
\text { (2) }\end{array}$ & $\begin{array}{c}\text { Herbicides } \\
\text { available } \\
\text { (3) }\end{array}$ & $\begin{array}{c}\text { Fully } \\
\text { constrained } \\
\text { (4) }\end{array}$ & $\begin{array}{c}\text { Delete } \\
\text { dispersion } \\
\text { (5) }\end{array}$ & $\begin{array}{l}\text { Herbicides } \\
\text { available } \\
\text { (6) }\end{array}$ \\
\hline LRSYA (MMCF) & 350 & 350 & 533 & 350 & 350 & 540 \\
\hline $\begin{array}{l}\text { First decade } \\
\text { harvest (MMCF) }\end{array}$ & 421 & 488 & 421 & 698 & 793 & 740 \\
\hline $\begin{array}{l}\text { Five-decade } \\
\text { harvest (MMCF) }\end{array}$ & 2,142 & 2,678 & 2,120 & 2,083 & 2,880 & 2,028 \\
\hline $\begin{array}{l}\text { First decade } \\
\text { cost }(\mathrm{MM} \$)\end{array}$ & 161 & 156 & 150 & 234 & 311 & 271 \\
\hline $\begin{array}{l}\text { Five-decade } \\
\text { cost }(\mathrm{MM} \$)\end{array}$ & 1,161 & 1,570 & 1,269 & 1,052 & 1,508 & 1,158 \\
\hline $\begin{array}{l}\text { First decade } \\
\text { revenue (MM\$) }\end{array}$ & 655 & 575 & 657 & 1,317 & 1,453 & 1,396 \\
\hline $\begin{array}{l}\text { Five-decade } \\
\text { revenue (MM\$) }\end{array}$ & 6,281 & 5,961 & 6,274 & 5,722 & 6,792 & 5,469 \\
\hline PNB (MM\$) & 3,916 & 4,128 & 3,932 & 2,453 & 3,162 & 2,431 \\
\hline PNW (MM\$) & 2,383 & 1,983 & 2,332 & 2,453 & 3,162 & 2,431 \\
\hline $\begin{array}{l}\text { Douglas-fir } \\
\text { first decade (perc }\end{array}$ & cent) & 64 & 74 & 57 & 69 & 51 \\
\hline $\begin{array}{l}\text { Douglas-fir } \\
\text { five-decade (perce }\end{array}$ & cent) 63 & 69 & 62 & 64 & 69 & 63 \\
\hline $\begin{array}{l}\text { Conventional loggir } \\
\text { first decade (perc }\end{array}$ & $\begin{array}{ll}\text { ing } & 90 \\
\text { cent) } & \end{array}$ & 99 & 93 & 82 & 69 & 86 \\
\hline $\begin{array}{l}\text { Conventional loggir } \\
\text { five-decade (perce }\end{array}$ & $\begin{array}{ll}\text { ing } & 77 \\
\text { cent) }\end{array}$ & 73 & 77 & 75 & 70 & 77 \\
\hline $\begin{array}{l}\text { Clearcut } \\
\quad \text { first decade (perc }\end{array}$ & cent) & 85 & 80 & 86 & 91 & 87 \\
\hline $\begin{array}{l}\text { Clearcut } \\
\text { five-decade (perce }\end{array}$ & cent) 54 & 86 & 55 & 67 & 88 & 70 \\
\hline
\end{tabular}


Deletion of the constraint under PNB/DSD results in a 16-percent increase in firstdecade harvest and a 25-percent increase in first-five-decades total harvest. Similar impacts occur under PNW/HD: 17-percent and 38-percent, respectively. The long-run sustained-yield average is not influenced because the dispersion constraint acts as a limiting force only on the liquidation rate of the old growth during the conversion period. As the forest becomes regulated, the constraint becomes slack. Because of differing price assumptions, impacts on revenues differ under each objective function. Under $\mathrm{PNB} / \mathrm{DSD}$, first-decade revenues decrease by 12 percent as output is expanded in the elastic region of the demand curve. The 16-decade present net revenue of the $\mathrm{PNB} / \mathrm{DSD}$ schedule drops by 17 percent. When a horizontal demand curve is assumed under PNW/HD, first-decade revenues increase by 10 percent and 16-decade present net revenues increase by 29 percent. As expected, more clearcutting is scheduled when the dispersion constraint is removed. The effects of the harvest and the logging system on species composition, however, follow no consistent pattern.

The increased harvest and revenues (under PNW/HD) would be offset by a decrease in environmental quality of forest elements, such as the visual and water resources. Before an informed judgement of the constraint can be made, the magnitude of environmental quality degradation must be estimated. Policy makers must then weigh the relevant benefits and costs of any proposed course of action.

\section{Herbicides}

Herbicides, such as 2,4-D and atrazine/dalapon, have been commonly used silvicultural tools for activities such as site preparation and release. In comparison to the major alternative-manual release-herbicides have the advantage of significant cost savings. The cost of manual release is sufficiently higher that on many forests a substantial backlog of acres will not receive release prescriptions in the absence of herbicides.

Since the early 1970s, the noneconomic costs of herbicide use have begun to overshadow the financial savings. As public sensitivity to the quality of life in the context of environmental quality has increased, political pressures against herbicide use have increased dramatically. Public groups have staged demonstrations, helicopters have been shot at, and in California the State Resources Agency has formally appealed to the Forest Service for the delay of herbicide use on the Six Rivers National Forest. In short, the political climate is not conducive to widespread herbicide use.

To model the effects of herbicide use on the harvest schedule, separate yield tables were constructed under the assumptions of availability and nonavailability. The perhaps extreme assumption was made that no site release prescriptions would be carried out if herbicides were not available. As such, the results constitute high-bound estimates. Yield tables reflecting availability of herbicides contain an accelerated time between stand establishment and first commercial thinning volumes and a reduced stand density in comparison to the yield tables reflecting herbicide nonavailability. Separate runs were made with each set of yield tables to isolate the effects of herbicide use.

The results indicate that the single most significant effect of herbicides is on the longrun productivity of the forest (Table 17). The long-run sustained-yield average increases by approximately 50 percent when herbicides are available (under both objective function/price formulations). The availability of herbicides does not significantly affect the indices associated with liquidation of the old-growth inventories. The explanation for this is found in the absence of the nondeclining-yield constraint. Without the NDY 
constraint, there is no allowable cut effect (ACE) associated with growth enhancement activities in subsequent rotations. If the nondeclining-yield constraint were included, the liquidation rate of the old-growth stands as indicated by the first-decade harvest level would be expected to increase substantially with the use of herbicides. (In a run which included the NDY constraint, which was made but not reported in this study, first-decade harvest increased by 26 percent when herbicides were made available.)

As with the dispersion or any other constraint on timber management, the benefits of imposing the constraint (or removing the constraint) must be weighed against the costs. As the study points out, another element-the NDY constraint-has a pivotal effect on the benefits associated with herbicide use.

\section{CURRENT SCENARIO AND PLAUSIBLE ALTERNATIVE}

The notion of concentrating intensive timber management on fewer acres and thereby freeing up acres for nontimber uses has been discussed within the forestry profession for several years. The most recent inquiry into such a trade-off strategy was conducted by Forest Service analysts on several western National Forests (Randall, et al., 1979; Hrubes, Connaughton, and Sassaman, 1979). Their results showed that it is not possible to maintain National Forest harvest levels under a strategy of intensive management of fewer acres (i.e., greater capital investment in timber management on a reduced land base). The explanation for this is that the environmental constraints, not the availability of capital, limit harvest levels most significantly. Greater timber management investments are not effective in increasing or maintaining allowable harvest levels when environmental constraints are not relaxed.

The 1979 study by Hrubes, Connaughton, and Sassaman did not consider the possibility of relaxing environmental constraints on the reduced land base, but the runs contained in this study allow just such an examination. The comparison is between the harvest schedule for the large land base, fully constrained (the closest approximation to the actual situation on the Six Rivers and other National Forests), and the schedule for the small land base, unconstrained. (For each objective function, the comparison is between $L L, \ldots, C 2$ and $S L, \ldots, U$.) Whereas in previous trade-off studies no increased environmental costs were allowed on the reduced land base (a "having your cake and eating it, too" situation, with nontimber interests doing the eating), the current comparison implies an acceptance of some increased environmental costs. It could be argued that without some increase in environmental costs no real trade-off is involved, and as the 1979 study revealed a trade-off strategy will not succeed if higher environmental costs are not allowed on the reduced land base. Further, this trade-off strategy allows for removal of the nondeclining constraint on the reduced land base. This case study suggests that the success of the trade-off strategy (in terms of maintaining harvest levels on a reduced land base) is enhanced when the nondeclining-yield constraint is removed.

Re-examining the tables leads to some basic conclusions. In terms of the index of greatest interest to past trade-off discussions-harvest levels-the success of the trade-off strategy depends on which objective function drives the scheduling process (Table 4). If the trade-off were implemented, first-decade harvest levels would increase by 17 percent under PNB/DSD maximization and by 218 percent under PNW/HD maximization. First-decade harvest would decrease by 9 percent under volume maximization. The strategy is less effective from the perspective of the Resource Planning Act (RPA) planning period. The first-five-decade total harvest level would be just maintainable under 
PNB/DSD maximization, would drop 17 percent under PNW/HD maximization, and would drop by 9 percent under volume maximization. The long-run sustained-yield average would decrease by 11 percent under PNB/DSD, 12 percent under $\mathrm{PNW} / \mathrm{HD}$, and 9 percent under volume maximization. The greater short-run effectiveness of the trade-off is attributable in large part to removal of the nondeclining-yield constraint, allowing accelerated old-growth liquidation. After the old-growth stands are liquidated, the major benefit of the trade-off ceases to exist.

While the strategy is not totally successful in the short run under PNW/HD and volume maximization, allowing higher environmental costs on the reduced land base results in significant harvest-level gains. By removing the environmental constraints on the small land base, 54 percent of the five-decade harvest loss due to land withdrawal is regained under $\mathrm{PNW} / \mathrm{HD}, 74$ percent under volume maximization, and 101 percent under PNB/DSD maximization.

The trade-off strategy would result in a general increase in the concentration of Douglas-fir harvest, both in the first decade and over the first five decades (Tables 8 to 11). The effect of the strategy on logging methods shows no clear trend, but the use of clearcutting is increased under all objective functions-both during the first decade and over the five-decade RPA planning period.

A re-examination of Tables 13 to 15 is complicated by the confusing nature of alternative price assumptions. Each schedule, whether driven by PNB/DSD or PNW/HD maximization, has associated with it a 16-decade present net benefit and present net worth. Under the price format of "maximize PNB with downward-sloping demand," the trade-off strategy results in a 4-percent drop in present net benefit and a 13-percent drop in present net worth. When the trade-off strategy is implemented under a "maximize PNW with horizontal demand" format, both present net benefit and present net worth drop by 3 percent (since PNB is equal to PNW under the horizontal demand assumption). First-decade total costs increase with the trade-off strategy by 90 percent for $\mathrm{PNB} / \mathrm{DSD}, 28$ percent for $\mathrm{PNW} / \mathrm{HD}$, and 33 percent for volume maximization. First-decade costs per MMCF increase by 63 percent for PNB/DSD, 22 percent for $\mathrm{PNW} / \mathrm{HD}$, and 47 percent for volume maximization.

In short, harvests are not quite maintainable except when PNB/DSD maximization drives the scheduling process, but the trade-off is more successful in maintaining harvests than has been shown in the results using the ground rules of previous trade-off studies. There would be a greater concentration on Douglas-fir and more use of clearcutting. The present value of net revenues to the Federal Treasury and the present value of net benefits (consumers' and producers' surplus) would be reduced. First-decade costs would increase even if the harvest level would not. And on the reduced land base, the removal of environmental constraints would result in shorter rotations, geographic concentration of harvest, accelerated liquidation of old-growth stands, and possible hazards attendant to the use of herbicides and pesticides. 


\section{SUMMARY}

The timber harvest capability of a National Forest as determined in the allowable harvest/sustained-yield framework is limited at the extensive and intensive margins by considerations for the other uses and attributes of forest land. This case study has generated quantitative information showing how the extensive and intensive margins of timber management are affected by other uses and attributes that can loosely be called "environmental considerations."

These findings confirm that the allowable harvest capability of the case forest is significantly reduced when measures are taken (i.e., constraints or limits or both are imposed) to attain environmental goals. The long-run sustained-yield capacity is reduced by up to 65 percent. At the extensive margin, environmentally related land withdrawal from the timber management land base is the single most significant influence. Limits on the minimum allowable rotation and on the use of chemicals in site release, geographic dispersion requirements, and retention of old-growth stands operate at the intensive margin to influence allowable harvest levels significantly.

While the effects of environmental considerations on the harvest capability are relatively unambiguous, their effects in monetary terms depend on the assumptions made about the market structure (and, as such, the price structure) under which National Forest stumpage is sold. In the case in which the Forest Service is argued to possess significant market power-both because of the structure of the market and because of the assumed behavior of all National Forests in the market-meeting environmental goals by restricting timber output is consistent with goals for maximizing returns to the Treasury. No financial opportunity costs are associated with meeting environmental goals. To the contrary, environmental considerations enhance, however inadvertently, the supply position of the Forest Service when downward-sloping demand is the appropriate price formulation. Alternatively, meeting environmental goals results in monetary costs in the form of foregone revenues when it is determined that market structure and National Forest supply behavior are consistent with a horizontal demand price formulation.

The ultimate value of the quantitative information generated in this case study and in similar analyses for other National Forests is in its ability to aid policy and decision makers in making informed choices in fundamental management decisions. A knowledge of relative costs and benefits is critical to arriving at those decisions and actions that best meet the overall goals of National Forest management.

\section{ACKNOWLEDGMENTS}

I thank Klaus Barber, U.S. Department of Agriculture, Forest Service, San Francisco, California, for providing the data used in this case study, and for his timely and skillful assistance in the operational phases of the simulation work reported in this paper. I am also indebted to John Zivnuska, Professor Emeritus, Department of Forestry and Conservation, University of California, Berkeley, for his insightful comments and suggestions. 


\section{LITERATURE CITED}

BERCK, P.

1979. The economics of timber: a renewable resource in the long run. Bell. J. Econ. vol. 10, no. 2:447-62.

DAVIS, K. P.

1954. American Forest Management. McGraw-Hill, New York. 519 pp.

HAYNES, R. W., K. P. CONNAUGHTON, and D. M. ADAMS

1980. Stumpage price projections for selected western species. USDA Forest Service Research Note PNW-367, Pacific Northwest Forest and Range Experiment Station, Portland, Oregon.

1981. Projections of the demand for national forest stumpage, by region, 1980-2030. USDA Forest Service Research Paper PNW-282, Pacific Northwest Forest and Range Experiment Station, Portland, Oregon. 13 pp.

HRUBES, R. J.

1981. The USDA Forest Service in the environmental era: institutional and programmatic change. $\mathrm{PhD}$ thesis. University of California, Berkeley. 272 pp.

HRUBES, R. J., K. P. CONNAUGHTON, and R. W. SASSAMAN

1979. Roadless area-intensive management tradeoffs on the Sierra National Forest, California. USDA Forest Service Research Paper PSW-149, Pacific Southwest Forest and Range Experiment Station, Berkeley, California. 11 pp.

JOHNSON, K. NORMAN

1979. FORPLAN User's Manual. USDA Forest Service, Ft. Collins, Colorado.

JOHNSON, K. N., and H. L. SCHEURMAN

1977. Techniques for prescribing optimal timber harvest and investment under different objectives. Forest Science Monograph 18. 31 pp.

MEAD, W. J.

1966. Competition and oligopsony in the Douglas-fir lumber industry. Univ. Calif. Press, Berkeley. 276 pp.

RANDALL, R. M., R. D. FIGHT, K. N. JOHNSON, K. P. CONNAUGHTON, and R. W. SASSAMAN.

1979. Roadless area-intensive management tradeoffs on Pacific northwest national forests. Research Paper PNW-258, Pacific Northwest Forest and Range Experiment Station, USDA Forest Service, Portland, Oregon. 69 pp.

ROW, C., H. FRED KAISER, and J. SESSIONS

1981. Discount rate for long-term Forest Service investments. J. For., vol. 79:6. pp. 367-68.

USDA FOREST SERVICE

1969. Douglas-fir supply study; alternative programs for increasing timber supplies from national forest lands. Pacific Northwest Forest and Range Experiment Station, Portland, Oregon. 53 pp.

U.S. WATER RESOURCES COUNCIL

1974. OBERS projections. vol. 4: States. Washington, D.C.

VAUX, H. J., and J. A. ZIVNUSKA

1952. Forest production goals: a critical analysis. Land Economics 18(4):318-27.

WALKER, J. L.

1971. An economic model for optimizing the rate of timber harvesting. PhD thesis, University of Washington, Seattle, $177 \mathrm{pp}$. 


\section{APPENDIX A \\ DERIVATION OF FOREST DEMAND CURVES FROM REGIONAL DEMAND CURVES}

\section{Central assumption:}

The regional price elasticity of demand at an equilibrium price/output combination is equal to the forest level price elasticity of demand at the corresponding local equilibrium price/output combination.

\section{Data provided:}

- Regional demand curve (Haynes, et al., 1981)

$\mathrm{P}_{\mathrm{MBF}}=93.06-.161 \mathrm{Q}_{\mathrm{MCF}}$

(1967 dollars)

- 1980 regional price/output combination (Haynes, et al., 1981)

$$
\mathrm{Q}=327 \text { MMCF, } \mathrm{P}=40.4 \quad \text { (1967 dollars per MBF) }
$$

- 1980 Six Rivers price/output combination (personal communication, Klaus Barber, USDA Forest Service, San Francisco)

$\mathrm{Q}=160 \mathrm{MMBF}, \mathrm{P}=303$

(1967 dollars per MBF)

\section{Procedure:}

Step 1: Convert regional demand to board feet measure.

Assume 5 board feet equals 1 cubic foot. (Price elasticity is not affected by the conversion ratio. The conversion is made to obtain a demand equation with the same measurement units for price and quantity.)

Step 2: Determine price elasticity at 1980 regional $P / Q$ combination.

$$
\begin{aligned}
\eta=\frac{\frac{\Delta \mathrm{Q}}{-\mathrm{Q}}}{\frac{\Delta \mathrm{P}}{\mathrm{P}}} & =\frac{-\Delta \mathrm{Q}}{\Delta \mathrm{P}} \times \frac{\mathrm{P}}{\mathrm{Q}} \\
& =\frac{1}{\text { slope }} \times \frac{40.4}{1,635} \\
& =31.056 \times \frac{40.4}{1,635}=.767
\end{aligned}
$$


Step 3: Determine Six Rivers demand curve by finding slope through $1980 \mathrm{P} / \mathrm{Q}$ combination such that $\eta=.767$.

$$
(\mathrm{P}, \mathrm{Q})=(303,160 \mathrm{MMBF})
$$

$303(\$ / \mathrm{MBF})=\alpha+\mathrm{b} \times 160 \mathrm{MMBF}$

$$
\begin{aligned}
& \mathrm{b}=\frac{\Delta \mathrm{P}}{\Delta \mathrm{Q}},-\frac{\frac{\Delta \mathrm{Q}}{\mathrm{Q}}}{\frac{\Delta \mathrm{P}}{\mathrm{P}}}=.767 \\
&-\frac{\Delta \mathrm{Q}}{\mathrm{Q}} \times \frac{\mathrm{P}}{\Delta \mathrm{P}}=.767 \\
& \frac{\Delta \mathrm{P}}{\mathrm{Q}}=-2.467=\text { slope } \\
& \frac{\Delta \mathrm{P}}{\Delta \mathrm{Q}}=-\frac{\mathrm{P}}{\mathrm{Q}} \times \frac{1}{.767} \\
& \therefore \mathrm{P}(\$ / \mathrm{MBF})=697-2.467 \mathrm{QMMBF} \\
& \mathrm{P}(\$ / \mathrm{MBF})=3,485-.0617 \mathrm{Q}_{\mathrm{MCF}} \\
& \text { or }
\end{aligned}
$$




\section{APPENDIX B}

\section{PROOF THAT LOCAL AND REGIONAL PRICE ELASTICITIES ARE EQUAL UNDER FIXED PROPORTIONS}

Fixed proportions:

$$
\begin{aligned}
\text { Let } \mathrm{Q} & =\text { regional National Forest output } \\
\mathrm{k}_{\mathrm{i}} & =\text { share from } \mathrm{i}^{\text {th }} \text { forest } \\
\therefore \mathrm{Q}_{\mathrm{i}} & =\text { output from } \mathrm{i}^{\text {th }} \text { forest }=\mathrm{k}_{\mathrm{i}} \mathrm{Q} \\
\text { and } & \\
\Delta \mathrm{Q}_{\mathrm{i}} & =\mathrm{k}_{\mathrm{i}} \Delta \mathrm{Q}
\end{aligned}
$$

Regional demand:

$$
\begin{aligned}
& \mathrm{P}=\alpha+\beta \mathrm{Q} \\
& \text { where } \beta=\frac{\Delta \mathrm{P}}{\Delta \mathrm{Q}}
\end{aligned}
$$

Forest demand with fixed proportions:

$$
\begin{aligned}
\mathrm{P} & =\alpha_{\mathrm{i}}+\beta_{\mathrm{i}} \mathrm{Q}_{\mathrm{i}} \\
\beta_{\mathrm{i}} & =\frac{\Delta \mathrm{P}}{\Delta \mathrm{Q}_{\mathrm{i}}}=\frac{\Delta \mathrm{P}}{\mathrm{k}_{\mathrm{i}} \Delta \mathrm{Q}}=\frac{1}{\mathrm{k}_{\mathrm{i}}} \times \beta \\
\alpha_{\mathrm{i}} & =\mathrm{P}-\beta_{\mathrm{i}} \mathrm{Q}_{\mathrm{i}}=\mathrm{P}-\frac{1}{\mathrm{k}_{\mathrm{i}}} \beta \times \mathrm{k}_{\mathrm{i}} \mathrm{Q} \\
\alpha_{\mathrm{i}} & =\mathrm{P}-\beta \mathrm{Q}=\alpha
\end{aligned}
$$




\section{Proof:}

$$
\begin{aligned}
& \eta= \text { regional price elasticity }=\frac{\Delta \mathrm{Q}}{\mathrm{Q}} / \frac{\Delta \mathrm{P}}{\mathrm{P}} \\
& \eta_{\mathrm{i}}=\text { price elasticity for ith forest }=\frac{\Delta \mathrm{Q}_{\mathrm{i}}}{\mathrm{Q}_{\mathrm{i}}} / \frac{\Delta \mathrm{P}}{\mathrm{P}} \\
& \begin{aligned}
\eta_{\mathrm{i}}=\frac{\frac{\Delta \mathrm{Q}_{\mathrm{i}}}{\mathrm{Q}_{\mathrm{i}}}}{\frac{\Delta \mathrm{P}}{\mathrm{P}}} & =\frac{\Delta \mathrm{Q}_{\mathrm{i}}}{\Delta \mathrm{P}} \times \frac{\mathrm{P}}{\mathrm{Q}_{\mathrm{i}}} \\
& =\frac{1}{\beta_{\mathrm{i}}} \times \frac{\mathrm{P}}{\mathrm{Q}_{\mathrm{i}}} \\
& =\frac{\mathrm{k}_{\mathrm{i}}}{\beta} \times \frac{\mathrm{P}}{\mathrm{k}_{\mathrm{i}} \mathrm{Q}} \\
& =\frac{1}{\beta} \times \frac{\mathrm{P}}{\mathrm{Q}} \\
& =\eta \\
\therefore \eta_{\mathrm{i}} & =\eta
\end{aligned}
\end{aligned}
$$


